\title{
613 cases of splenic rupture without risk factors or previously diagnosed disease: a systematic review
}

F Kris Aubrey-Bassler ${ }^{1,2,3^{*}}$ and Nicholas Sowers ${ }^{4}$

\begin{abstract}
Background: Rupture of the spleen in the absence of trauma or previously diagnosed disease is largely ignored in the emergency literature and is often not documented as such in journals from other fields. We have conducted a systematic review of the literature to highlight the surprisingly frequent occurrence of this phenomenon and to document the diversity of diseases that can present in this fashion.
\end{abstract}

Methods: Systematic review of English and French language publications catalogued in Pubmed, Embase and CINAHL between 1950 and 2011.

Results: We found 613 cases of splenic rupture meeting the criteria above, 327 of which occurred as the presenting complaint of an underlying disease and 112 of which occurred following a medical procedure. Rupture appeared to occur spontaneously in histologically normal (but not necessarily normal size) spleens in 35 cases and after minor trauma in 23 cases. Medications were implicated in 47 cases, a splenic or adjacent anatomical abnormality in 31 cases and pregnancy or its complications in 38 cases.

The most common associated diseases were infectious $(n=143)$, haematologic $(n=84)$ and non-haematologic neoplasms $(n=48)$. Amyloidosis $(n=24)$, internal trauma such as cough or vomiting $(n=17)$ and rheumatologic diseases $(n=10)$ are less frequently reported. Colonoscopy $(n=87)$ was the procedure reported most frequently as a cause of rupture. The anatomic abnormalities associated with rupture include splenic cysts $(n=6)$, infarction $(n=6)$ and hamartomata $(n=5)$. Medications associated with rupture include anticoagulants $(n=21)$, thrombolytics $(n=13)$ and recombinant $G-C S F(n=10)$. Other causes or associations reported very infrequently include other endoscopy, pulmonary, cardiac or abdominal surgery, hysterectomy, peliosis, empyema, remote pancreato-renal transplant, thrombosed splenic vein, hemangiomata, pancreatic pseudocysts, splenic artery aneurysm, cholesterol embolism, splenic granuloma, congenital diaphragmatic hernia, rib exostosis, pancreatitis, Gaucher's disease, Wilson's disease, pheochromocytoma, afibrinogenemia and ruptured ectopic pregnancy.

Conclusions: Emergency physicians should be attuned to the fact that rupture of the spleen can occur in the absence of major trauma or previously diagnosed splenic disease. The occurrence of such a rupture is likely to be the manifesting complaint of an underlying disease. Furthermore, colonoscopy should be more widely documented as a cause of splenic rupture.

Keywords: Splenic rupture, Rupture, Spontaneous, Atraumatic, Presenting complaint, Initial manifestation

\footnotetext{
* Correspondence: kaubrey@mun.ca

${ }^{1}$ Primary Healthcare Research Unit, Memorial University of Newfoundland, Health Sciences Centre, St. John's, Newfoundland and Labrador, St Johns,

Canada

${ }^{2}$ Discipline of Emergency Medicine, Memorial University of Newfoundland, St. John's, Newfoundland and Labrador, St Johns, Canada

Full list of author information is available at the end of the article
}

\section{Biomed Central}

(c) 2012 Aubrey-Bassler and Sowers; licensee BioMed Central Ltd. This is an Open Access article distributed under the terms of the Creative Commons Attribution License (http://creativecommons.org/licenses/by/2.0), which permits unrestricted use, distribution, and reproduction in any medium, provided the original work is properly cited. 


\section{Background}

Rupture of the spleen is relatively common both immediately and in a delayed fashion following significant blunt abdominal injury [1], and this phenomenon is well documented in the scientific literature and textbooks (e.g. $[2,3])$. While less common, cases of atraumatic rupture of diseased spleens are also widely reported in the literature (reviewed in $[4,5])$. In contrast, the phenomenon of splenic rupture in the absence of these two risk factors is not documented in emergency medicine textbooks [2,3] and we believe that it is not widely appreciated by emergency physicians.

Cases of splenic rupture not fitting the description above are related by their lack of historical cues to suggest the diagnosis at presentation. This distinguishes them from other causes of splenic rupture and highlights the importance to emergency physicians who rely a great deal on the patient history to appropriately triage patients for definitive investigation and referral. A recent systematic review of cases of atraumatic rupture of the spleen has been published [4]; however, a surprising number of the splenic rupture cases reported in this review and elsewhere represent the presenting complaint of the underlying disease process. The authors of the review do not highlight this fact which we believe to be crucial information to the practicing clinician. Therefore, we have reviewed the literature on cases of splenic rupture for which there was not an immediately obvious cause apparent on presentation such as significant trauma (either recent or remote) or previously diagnosed disease known to affect the spleen.

\section{Methods}

We conducted a systematic review of English and French language papers indexed in CINAHL, PubMed and Embase using the medical subject heading (MeSH) search terms "rupture, spontaneous," and "splenic rupture," (or equivalent for the different databases) combined with the textword search "undiagnosed" or "first manifestation" or "presenting" or "spontaneous." This search strategy was combined with an additional strategy including the MeSH terms "rupture, spontaneous" and "spleen" and the free text "normal spleen;" both strategies were used together to extract relevant papers. Searches were limited to English and French language papers on human subjects published in the years 1950 to 2011. We also explored multiple other textword modifiers such as "atraumatic," "non-traumatic" and "trivial," none of which improved the sensitivity of the search with sufficient specificity to be helpful. Searches were developed by a research librarian and one of the authors who has training in clinical epidemiology (KA).

The reference lists of the papers so identified were also examined for relevant additions. We elected to include papers written in other languages if an English language abstract was available that included the information necessary for our report. Because the information we were trying to extract was fairly straightforward, we elected to include cases from papers for which only the abstract was available to us if the necessary information was reported there.

Case reports and case series' were examined for relevance. Data was extracted from cases referenced in

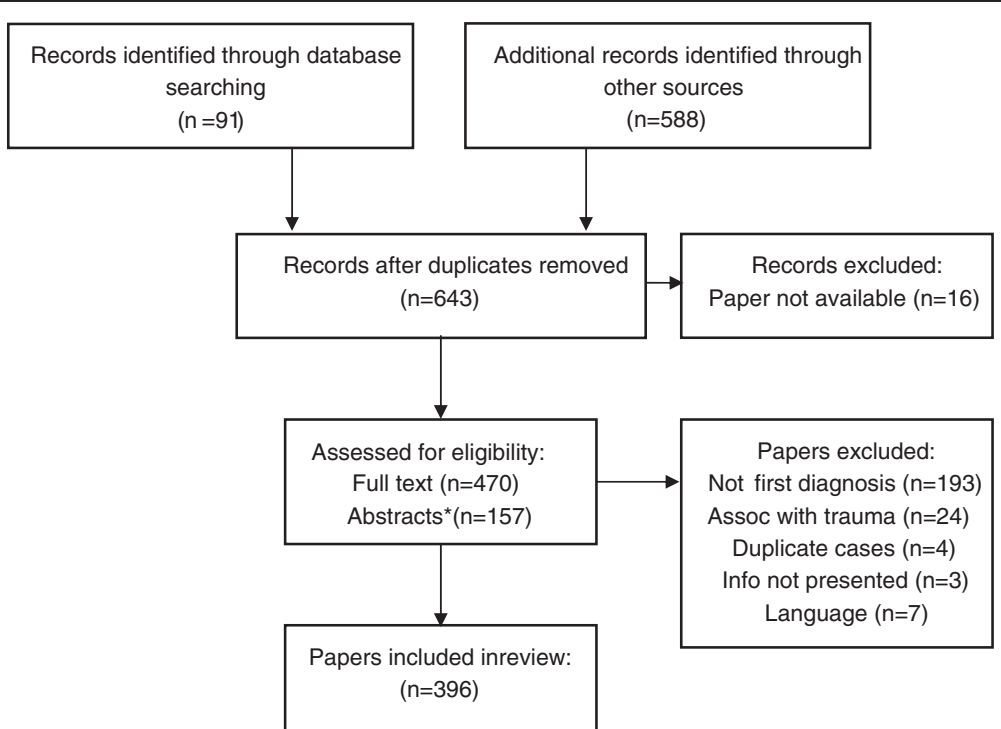

Figure 1 PRISMA [7] flow diagram documenting number of references processed. Legend: *Only abstracts containing all necessary information were included. Abbreviations: Assoc $=$ associated. 


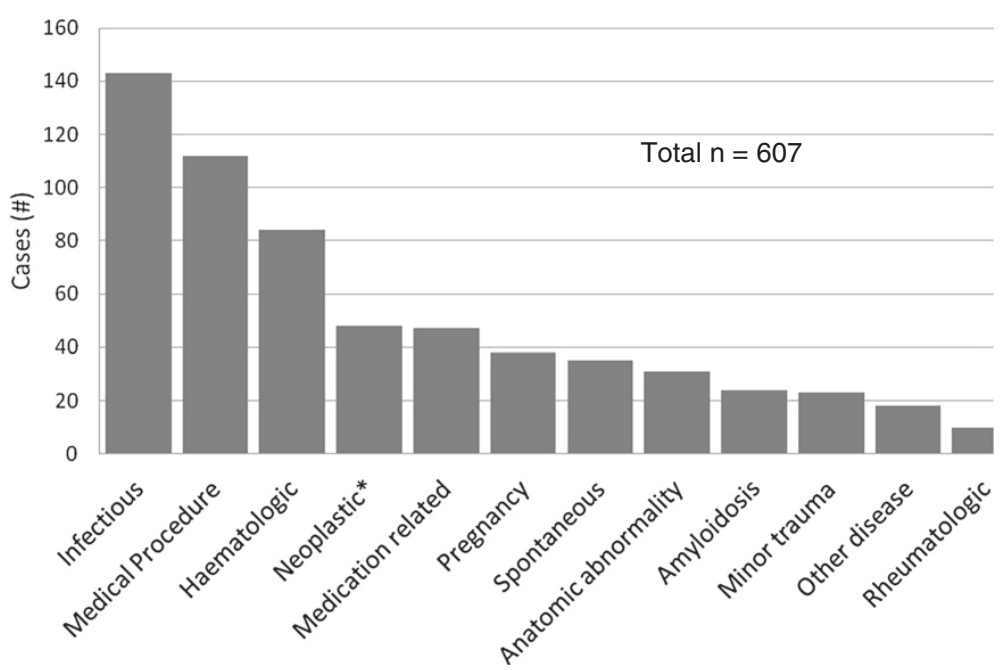

Figure 2 Categorization of all splenic rupture cases meeting inclusion criteria. Legend: * Non-haematologic only; haematologic neoplasms are contained in the haematologic category.

review papers only if the original paper was not available to us, and these were cross-referenced with case reports to prevent duplicate recording. Papers pertaining to the rupture of diseased spleens were excluded if the disease was correctly diagnosed prior to presentation at the emergency department. Cases of splenic rupture occurring immediately following any trauma (including trivial) were also excluded. Delayed splenic rupture cases were excluded if they occurred greater than 48 hours after major trauma (because this phenomenon is well reported in the literature and textbooks), but were included if the inciting traumatic event was considered by the two authors to be of trivial severity. Although the degree of trauma is debatable, we elected to include cases likely caused by cough or vomiting because we felt that these aetiologic factors were also under-appreciated. Although delayed post-medical procedure rupture of the spleen is documented in the proceduralist (surgical and GI) literature, it is not documented in EM textbooks and we have elected to include these cases here. We limited our report to papers published since 1950. Although the diagnosis and treatment of splenic rupture has changed considerably in recent years, we found no evidence to suggest that the underlying causes of rupture have changed during this time period. Because the primary purpose of our paper was to highlight aetiology and not diagnosis or management, we elected to choose a somewhat broader time period than might have been appropriate for a study with a different purpose. The information extracted onto a spreadsheet included the splenic disease process if any, other evidence of splenic abnormality (anatomical or histological), and the nature of any associated trauma. Causative processes were grouped into clinically relevant categories. We did not attempt to document histological or pathological findings, or review diagnostic or treatment methods as these are recently reviewed in detail elsewhere $[4,5]$.

\section{Results}

No Medical Subject Headings or other keywords reliably identified the 396 papers reporting 607 cases of splenic rupture that met our inclusion criteria. Thus, we manually reviewed many abstracts and papers that ended up being excluded from this review (Figure 1). Some case series referenced here report both cases meeting our inclusion criteria and others meeting our exclusion criteria; only those meeting the inclusion criteria are included. We attempted to obtain all of the original papers referenced here so that we could document the

Table 1 Cases of splenic rupture following a medical procedure

\begin{tabular}{lllll}
\hline Procedure & $<\mathbf{4 8}$ hours & References & $\mathbf{> 4 8}$ hours & References \\
\hline Colonoscopy & 79 & {$[8-20]$} & 8 & {$[10,11,21-23]$} \\
ERCP & 4 & {$[24-27]$} & 4 & {$[28-31]$} \\
Liver surgery & 5 & {$[32-36]$} & & \\
Pulmonary Surgery & 2 & {$[37,38]$} & & \\
Gastroscopy & & & 1 & {$[39]$} \\
Displaced CAPD & & & 1 & {$[40]$} \\
catheter & & & & \\
ESWL & 1 & {$[41]$} & & \\
ECT & 1 & {$[42]$} & & \\
Abdominal surgery & 1 & {$[43]$} & & \\
Laparoscopy & 1 & {$[44]$} & & \\
Hysterectomy & 4 & {$[45-48]$} & & \\
TOTAL & $\mathbf{9 8}$ & & $\mathbf{1 4}$ & \\
\hline
\end{tabular}


Table 2 Cases of splenic rupture associated with previously undiagnosed infiltrative or inflammatory pathology

\begin{tabular}{|c|c|c|c|c|c|}
\hline \multirow{2}{*}{$\frac{\text { Disease }}{\text { Infectious }}$} & \multirow[t]{2}{*}{ Cases } & \multirow[t]{2}{*}{ References } & \multicolumn{3}{|l|}{$\overline{\text { Other }}$} \\
\hline & & & Amyloidosis & 24 & {$[65,206-216]$} \\
\hline Malaria & 65 & [49-60] & Peliosis & 8 & {$[217-224]$} \\
\hline Mononucleosis & 42 & [61-90] & Pancreatitis & 5 & {$[151,225-228]$} \\
\hline CMV & 6 & {$[91-95]$} & Gaucher's Disease & 1 & [80] \\
\hline Typhoid fever & 4 & {$[96,97]$} & Wilson's Disease & 1 & [229] \\
\hline Endocarditis with splenic embolism & 3 & [98-100] & Total & 276 & \\
\hline
\end{tabular}

HIV

Q fever

Salmonella sp.

Splenic tuberculosis

Viral Hepatitis

EBV

Babesiosis

Brucellosis

Bartonella

Dengue fever

Enterobacter cloacae

Murine typhus

Rickettsia sp.

Varicella

Haematologic

Non-Hodgkin's Lymphoma

Hodgkin's Lymphoma

Undifferentiated Lymphoma

Acute Lymphoblastic Leukemia

Chronic Myelogenous Leukemia

Acute Myelogenous Leukemia

Hairy Cell Leukemia

Acute T-cell Leukemia

Undfifferentiated Leukemia

Histiocytosis

Multiple Myeloma

Idiopathic Thrombocytic Purpura

Myelofibrosis

Polycythemia Vera

Sickle Cell Disease

Essential Thrombocythemia

Rheumatologic

Wegener's Granulomatosis

Polyarteritis Nodosa

Systemic Lupus Erythematosis

Rheumatoid Arthritis
[104-106]

$[107,108]$

[109,110]

$[111,112]$

$[113,114]$

[115]

[116]

[117]

[119]

[120]

[121]

[122]

[123]

[124-145]

[146-150]

[151-153]

[154-165]

[166-172]

[64,173-177]

[178-182]

[183]

[184]

[185-190]

$[63,191]$

[192]

[193]

[194]

[195]

[196]

[197-199]

[200,201]

[202-204]

[205]
Table 2 Cases of splenic rupture associated with previously undiagnosed infiltrative or inflammatory pathology (Continued)

Other

cases without relying on secondary sources. However, sixteen of the papers were not accessible to us nor were we able to find the information necessary to fully ascertain whether the cases described within them were appropriate for this review. All cases are categorized in Figure 2 and clinically relevant sub-categories are presented in Tables 1, 2, 3, 4, 5, 6.

\section{Discussion}

Although rupture of the spleen in the absence of previously diagnosed disease or trauma is widely described as rare, given the extensive reports in the literature documented here, we believe that this descriptor should no longer be used. Although its existence is debated [1,369,400-402], sufficient reports from multiple authors are available to strongly suggest that rupture can occur spontaneously in otherwise normal spleens, but that this phenomenon is very rare. Given these two facts, the emergency clinician must be attuned to the possibility of splenic rupture in patients presenting with compatible diagnosis of a splenic or adjacent physical abnormality

\begin{tabular}{lll}
\hline Diseases & Cases & References \\
\hline Splenic cyst & 6 & {$[6,61,230-233]$} \\
Splenic infarction & 6 & {$[234-238]$} \\
Splenic hamartoma & 5 & {$[239-243]$} \\
Hemangioma & 3 & {$[244-246]$} \\
Pancreatic pseudocyst & 2 & {$[247,248]$} \\
Thrombosed splenic vein & 2 & {$[249,250]$} \\
Splenic artery aneurysm & 1 & {$[251]$} \\
Empyema & 1 & {$[252]$} \\
Remote Pancreato-Renal Transplant & 1 & {$[253]$} \\
Cholesterol Embolism & 1 & {$[254]$} \\
Splenic granuloma & 1 & {$[255]$} \\
Congenital Diaphragmatic Hernia & 1 & {$[256]$} \\
Rib exostosis & 1 & {$[257]$} \\
TOTAL & $\mathbf{3 1}$ &
\end{tabular}

Table 3 Cases of splenic rupture associated with the first 
Table 4 Pregnancy related causes of splenic rupture

\begin{tabular}{lll}
\hline Cause & Cases & References \\
\hline Normal pregnancy & 22 & {$[257-278]$} \\
Splenic ectopic pregnancy & 9 & {$[279-287]$} \\
Post-vaginal delivery & 2 & {$[288,289]$} \\
Post-caesarean section & 2 & {$[290,291]$} \\
Preeclampsia & 1 & {$[292]$} \\
Ruptured ectopic pregnancy & 1 & {$[225]$} \\
Non-splenic & & \\
HELLP syndrome & 1 & {$[293]$} \\
Total & $\mathbf{3 8}$ &
\end{tabular}

Abbreviations: HELLP: Hemolysis, Elevated Liver Enzymes, Low Platelets.

symptoms without a compatible history. ED physicians must also be aware that such a presentation is very likely to be the manifesting episode of an underlying disease or anatomical abnormality. In the only other reference to these surprising findings, Renzulli found that the underlying cause for $51.2 \%$ of the cases of atraumatic splenic rupture was not elicited until after hospital presentation [4].

In 1958, Orloff and Peskin proposed four criteria to define a true spontaneous rupture of a spleen [206], which emphasize that the spleen must appear grossly and histologically normal. In the same paper, they cite 71 reports documenting ruptures of the spleen labelled as spontaneous, only 20 of which fulfilled all of their criteria. Thus, usage of the term spontaneous was inconsistent and continues to be so in the more recent literature, with many authors labeling the rupture of diseased spleens as spontaneous. We highlight this because many of the pathological ruptures that we have documented here (as well as pathological ruptures in patients with previously known disease documented elsewhere [6]) include the word spontaneous in the title and no information on the associated pathology $[8,61,91,98,124,151,154,355-357,365,400,403]$. Thus, readers skimming titles may be mistaken in thinking

Table 5 Previously undiagnosed, non-hematologic neoplastic causes of spontaneous splenic rupture

\begin{tabular}{lll}
\hline Cause & Cases & References \\
\hline Angiosarcoma & 31 & {$[294-309]$} \\
Choriocarcinoma & 5 & {$[310-315]$} \\
Pancreatic cancer & 4 & {$[316-319]$} \\
Gastric cancer & 1 & {$[320]$} \\
Lung cancer & 4 & {$[313,321-323]$} \\
Kaposi Sarcoma & 1 & {$[324]$} \\
Granulosa cell tumour & 1 & {$[325]$} \\
Myofibroblastic tumour & 1 & {$[326]$} \\
Total & $\mathbf{4 8}$ & \\
\hline
\end{tabular}

that true spontaneous rupture is more common than thought.

As we have shown here, documentation of rupture of the spleen following colonoscopy is relatively common with at least 87 cases reported (Table 2). However, we found only 1 such case reported in the emergency medicine literature [9], and no reference to this association in emergency medicine textbooks [2,3] or electronic resources [404]. Although many occurrences of these cases should be evident to the endoscopist at the time of or shortly after the procedure, at least 8 documented cases have presented to the ED greater than 48 hours afterwards [10,11,21-23]. We have therefore elected to include these and other post-procedure cases in this review. Rupture of the spleen after other procedures appears to be very rare.

For the cases presented here with pathology in addition to the splenic rupture, there is a plausible causative relationship between the other pathology and the rupture for the vast majority. However, we have also included cases with a less clear patho-physiological relationship, such as the case reported 3 years after a pancreato-renal transplant [253], and that associated with viral hepatitis but no cirrhosis [113]. We acknowledge that the association in these cases may be coincidental and thus that these cases may better be classified

Table 6 Other cases of splenic rupture

\begin{tabular}{|c|c|c|}
\hline Cause & Cases & References \\
\hline \multicolumn{3}{|l|}{ Medication related } \\
\hline Anticoagulant & 21 & {$[327-337]$} \\
\hline Thrombolytic & 13 & $\begin{array}{l}{[83,329} \\
338-342]\end{array}$ \\
\hline Recombinant G-CSF & 10 & {$[343-352]$} \\
\hline Anti-platelet agents & 2 & {$[353]$} \\
\hline HIT & 1 & {$[354]$} \\
\hline \multicolumn{3}{|l|}{ Internal trauma-related } \\
\hline Cough & 12 & $\begin{array}{l}{[98,151} \\
355-364]\end{array}$ \\
\hline Vomiting & 4 & {$[365-368]$} \\
\hline Seizure & 1 & {$[249]$} \\
\hline \multicolumn{3}{|l|}{ Miscellaneous } \\
\hline Spontaneous & 35 & $\begin{array}{l}{[43,61,63-65} \\
80,113,225 \\
249,369- \\
391]\end{array}$ \\
\hline$>48 \mathrm{~h}$ after minor external trauma & 6 & {$[249,392-396]$} \\
\hline Pheochromocytoma & 2 & {$[397,398]$} \\
\hline Afibrinogenemia & 1 & {$[399]$} \\
\hline TOTAL & 108 & \\
\hline
\end{tabular}

Abbreviations: G-CSF: Granulocyte Colony Stimulating Factor; HIT: Heparin Induced Thrombocytopenia. 
as spontaneous. Although Wilson's disease does not typically affect the spleen directly, the likely pathologic mechanism of the rupture in the case reported here is splenomegaly caused by portal hypertension [229].

We found only one case of delayed rupture of a normal spleen following trivial trauma reported in the literature in the last 60 years [392]. One other report of such a rupture in an enlarged but otherwise normal spleen [249], and reports of three others do not include information on the presence of splenic disease [393395]. One additional case has been reported in a man 14 days after a mild fall, but the patient had also just been given heparin for a presumed myocardial infarction [396]. Given the dearth of publication in this area, the possibility remains that the associations observed in these reports are coincidental rather than causational. Regardless of the causative mechanism, these cases still meet the inclusion criteria for this review.

\section{Limitations}

The primary goal of this paper is to highlight the occurrence of splenic rupture in patients without risk factors apparent on history. A secondary purpose is to document the diverse nature of illnesses that can present in this manner. However, we have not attempted to obtain papers that were not available to us either electronically, on paper at our library or through inter-library loan. We also have not attempted to have non-English or non-French language abstracts or papers translated. The possibility remains therefore that we have missed some rare causes of splenic rupture. In addition, while a general estimate of the relative frequency of different causes of splenic rupture can be made from the numbers reported here, the numbers for those that are frequently reported such as colonoscopy, malaria and lymphoma are likely underestimated because of publication bias. Conversely, the relative frequencies of rupture for rare or novel causes are likely over-estimated.

\section{Conclusions}

Both traumatic and pathological rupture of the spleen are frequently reported in journals and documented in textbooks of emergency medicine. However, other causes of rupture are largely ignored in the emergency literature. We have documented a diverse range of patients for whom the presenting complaint for a disease was rupture of the spleen. We have also documented a number of medical procedures and medications that appear to have contributed to a rupture of the spleen, including some that have presented after the patients had been discharged from the facility conducting the procedure. Finally, we have documented several cases of trivial trauma associated with splenic rupture. Although these categories at first glance seem unrelated, they share the characteristic of having causes of rupture that would either be very subtle or completely unapparent on the presenting history, and are thus directly relevant to the practicing emergency physician. We hope that increased awareness of these phenomena will improve the ability of emergency clinicians to diagnose similar cases of splenic rupture in a timely fashion.

\section{Competing interests}

The authors declare that they have no competing interests.

\section{Authors' contributions}

Both authors were involved in the literature search, review of the papers for inclusion, and the drafting of and revisions to the manuscript. KA takes full responsibility for the content. Both authors read and approved the final manuscript.

\section{Acknowledgements}

The authors wish to thank Shahil Sood for his assistance with some of the paper reviews and Ms Alison Farrell for her assistance with the literature search. This research was conducted with funding from the Primary Healthcare Research Unit and the Faculty of Medicine both at Memorial University of Newfoundland.

\section{Author details}

${ }^{1}$ Primary Healthcare Research Unit, Memorial University of Newfoundland, Health Sciences Centre, St. John's, Newfoundland and Labrador, St Johns, Canada. ${ }^{2}$ Discipline of Emergency Medicine, Memorial University of Newfoundland, St. John's, Newfoundland and Labrador, St Johns, Canada. ${ }^{3}$ Discipline of Family Medicine, Memorial University of Newfoundland, St. John's, Newfoundland and Labrador, St Johns, Canada. ${ }^{4}$ Department of Emergency Medicine, Dalhousie University, Halifax, NS, Canada.

Received: 9 February 2012 Accepted: 28 July 2012

Published: 14 August 2012

\section{References}

1. Olsen WR, Polley TZ Jr: A Second Look at Delayed Splenic Rupture. Arch Surg 1977, 112(4):422-425.

2. Tintinalli JE, Kelen GD, Stapczynski JS: Emergency Medicine: A Comprehensive Study Guide. 6th edition. New York: McGraw Hill; 2004.

3. Stone CK, Humphries RL: CURRENT Diagnosis \& Treatment: Emergency Medicine. 6th edition. available at: http://www.accessmedicine.com/content. aspx?alD=3099123:: Access Medicine; 2011.

4. Renzulli P, Hostettler A, Schoepfer AM, Gloor B, Candinas D: Systematic review of atraumatic splenic rupture. Br J Surg 2009, 96(10):1114-1121.

5. Debnath D, Valerio D: Atraumatic rupture of the spleen in adults. $J R$ Coll Surg Edinb 2002, 47:437-445.

6. Renzulli P, Schoepfer A, Mueller E, Candinas D: Atraumatic splenic rupture in amyloidosis. Amyloid 2009, 16(1):47-53.

7. Moher D, Liberati A, Tetzlaff J, Altman D, Antes G: Preferred reporting items for systematic reviews and meta-analyses: The PRISMA statement. PLoS Med 2009, 6(7):e1000097.

8. Randriamarolahy A, Cucchi JM, Brunner P, Garnier G, Demarquay J, Bruneton JN: Two rare cases of spontaneous splenic rupture. Clin Imaging 2010, 34(4):306-308.

9. Meier RPH, Toso C, Volonte F, Mentha G: Splenic rupture after colonoscopy. Am J Emerg Med 2011, 29:242. e1-242.e2.

10. Saad A, Rex DK: Colonoscopy-induced splenic injury: Report of 3 cases and literature review. Dig Dis Sci 2008, 53:892-898.

11. Petersen CR, Adamsen S, Gocht-Jensen P, Arnesen RB, Hart-Hansen O: Splenic injury after colonoscopy. Endoscopy 2008, 40:76-79.

12. DeVries J, Ronnen HR, Oomen APA, Linskens RK: Splenic rupture following colonoscopy, a rare complication. Neth J Med 2009, 67(6):230-233.

13. Arnaud JP, Bergamaschi R, Casa C, Boyer J: Splenic rupture: unusual complication of colonoscopy. Colo-proctology 1993, 6:356-357.

14. Guerra JF, San Francisco I, Pimentel F, Ibanez L: Splenic rupture following colonoscopy. World J Gastroenterol 2008, 14(41):6410-6412. 
15. Janes SEJ, Cowan IA, Dijkstra B: A life threatening complication after colonoscopy. BMJ 2005, 330(7496):889.

16. Lalor PF, Mann BD: Splenic rupture after colonoscopy. J Soc Laparoendocsopic Surgeons 2007, 11:151-156.

17. Rao KV, Beri GD, Sterling MJ, Salen G: Splenic injury as a complication of colonoscopy: a case series. Am J Gastroenterol 2009, 104(6):1604-1605.

18. Sarhan M, Ramcharan A, Ponnapalli S: Splenic injury after elective colonoscopy. J Soc Laparoendocsopic Surgeons 2009, 13:616-619.

19. Tse CCW, Chung KM, Hwang JST: Prevention of splenic injury during colonoscopy by positioning the patient. Endoscopy 1998, 30:74-75.

20. Wiedmann MW, Kater F, Bohm B: Splenic rupture following endoscopic polypectomy. Z Gastroenterol 2010, 48(4):476-478.

21. Ahmed A, Eller PM, Schiffman FJ: Splenic rupture: an unusual complication of colonoscopy. Am J Gastroenterol 1997, 92:1201-1204.

22. Merchant AA, Cheng EH: Delayed splenic rupture after colonoscopy. Am J Gastroenterol 1990, 85(7):906-907.

23. Taylor FC, Frankl HD, Riemer KD: Late presentation of splenic trauma after routine colonoscopy. Am J Gastroenterol 1989, 84(4):442-443.

24. Zyromski NJ, Camp CM: Splenic Injury: A Rare Complication of Endoscopic Retrograde Cholangiopancreatography. Am Surg 2004, 70(8):737-739

25. Lewis FW, Moloo N, Stiegmann GV, Goff JS: Splenic injury complicating therapeutic upper gastrointestinal endoscopy and ERCP. Gastrointest Endosc 1991, 37:632-633.

26. Furman G, Morgenstern L: Splenic injury and abscess complicating endoscopic retrograde cholangiopancreatography. Surg Endosc 1993, 7:343-344.

27. Kingsley D, Schermer C, Jamal M: Rare complications of endoscopic retrograde cholangiopancreatography: wo case reports. JSLS 2001, 5:171-173.

28. Tronsden E, Roseland AR, Moer A, Solheim K: Rupture of the spleen following endoscopic retrograde cholangiopancreotography (ERCP). Acta Chir Scand 1989, 155:75-76.

29. Ong E, Bohmler U, Wurgs D: Splenic injury as a complication of endoscopy: two case reports and a literature review. Endoscopy 1991, 23:302-304.

30. Lo AY, Washington M, Fischer MG: Splenic trauma following endoscopic retrograde cholangiopancreatography (ERCP). Surg EndosC 1994 8:692-693.

31. Wu WC, Katon RM: Injury to the liver and spleen after diagnostic ERCP. Gastrointest Endosc 1993, 39:824-827.

32. Baradaran S, Mischinger HJ, Bacher J, Werkgartner G, Karpf E, Linck FG Spontaneous splenic rupture during portal triad clamping. Langenbecks Arch Chir 1995, 380:266-268.

33. Ben-Haim M, Emre S, Fishbein T, Sheiner PA, Miller CM, Schwartz ME: Spontaneous splenic rupture during hepatic inflow occlusion (Pringle maneuver) or total vascular isolation. Liver Transp/ 2000, 6:C19. Abstract 77.

34. Douzdjian V, Broughan TA: Spontaneous splenic rupture during total vascular occlusion of the liver. Br J Surg 1995, 82:406-407.

35. Baniel J, Bihrle R, Wahle GR, Foster RS: Splenic rupture during occlusion of the porta hepatis in resection of tumors with vena caval extension. J Urol 1994, 151:992-994.

36. Kling N, Bechstein WO, Steinmüller T, Raakow R, Jonas S: Spontaneous splenic rupture during Pringle maneuvre in liver resection for hepatic abscess. Acta Chir Austr 1999, 31:261-263.

37. Klotz S, Semik M, Senninger N, Berendes E, Scheld HH: Spontaneous splenic rupture after a left-side thoracotomy: Report of a case. Surg Today 2003, 33(8):636-638.

38. Stupnik T, Vidmar S, Hari P: Spontaneous rupture of a normal spleen following bronchoplastic left lung lower lobectomy. Interact Cardiovasc Thorac Surg 2008, 7:290-291.

39. Hunter RCJ: Gastroscopy and delayed rupture of the spleen; a review and report of a possible case. Gastroenterology 1955, 29:898-906.

40. delos Santos CA, von Eye O, Vila D, Mottin CC: Rupture of the spleen: A complication of continuous ambulatory peritoneal dialysis. Perit Dial Int 1986, 6(4):203-204

41. Marcuzzi D, Gray R, Wesley-James T: Symptomatic splenic rupture following extracorporeal shock wave lithotripsy. J Urol 1991, 145:547-548.

42. Ernst D: Ruptured spleen after electric convulsion therapy. BMJ 1980, 280:763
43. Johnson N: Traumatic rupture of the spleen: a review of eighty-five cases. ANZ J Surg 1954, 24(2):112-124.

44. Chang MY, Shiau CS, Chang CL, Hou HC, Chiang CH, Hsieh TT, Soong YK: Spleen laceration, a rare complication of laparoscopy. J Am Assoc Gyecol Laparosc 2000, 7(2):267-272.

45. Bahli ZM, Kennedy K: Post hysterectomy spontaneous rupture of spleen J Ayub Med Coll Abbottabad 2009, 21(3):181-183.

46. Hoffman RL: Rupture of the spleen: a review and report of a case following abdominal hysterectomy. Am J Obstet Gynecol 1972, 113:524-530.

47. Habek D, Cerkez Habek J: Spontaneous splenic rupture of the spleen following abdominal hysterectomy. Zentralb/ Gynakol 2001, 123:588-589.

48. Heidenreich W, Mlasowsky B: Spontaneous splenic rupture as a cause of postoperative hemorrhage. Geburtshilfe Frauenheilkd 1986, 46:910-911.

49. Hamel CT, Blum J, Harder F, Kocher T: Nonoperative treatment of splenic rupture in malaria tropica: review of literature and case report. Acta Trop 2002, 82(1):1-5.

50. Imbert P, Rapp C, Buffet PA: Pathological rupture of the spleen in malaria: Analysis of 55 cases (1958-2008). Travel Med Infect Dis 2009, 7(3):147-159.

51. Patel Ml: Spontaneous rupture of a malarial spleen 16. Med J Aust 1993, 159(11-12):836-837

52. Ozsoy MF, Oncul O, Pekkafali Z, Pahsa A, Yenen OS: Splenic complications in malaria: Report of two cases from Turkey. J Med Microbiol 2004, 53 (12):1255-1258.

53. Zingman BS, Viner BL: Splenic complications in malaria: Case report and review. Clin Infect Dis 1993, 16(2):223-232.

54. Yagmur Y, Hamdi Kara I, Aldemir M, Buyukbayram H, Tacyildiz $\|_{\text {, }}$ Keles C: Spontaneous rupture of malarial spleen: two case reports and review of literature. Crit Care 2000, 4:309-313.

55. Gupta N, Lal P, Vindal A, Hadke NS, Khurana N: Spontaneous rupture of malarial spleen presenting as hemoperitoneum: a case report. J Vector Borne Dis 2010, 47:119-120.

56. Mokashi AJ, Shirahatti RG, Prabhu SK, Vagholkar KR: Pathological rupture of malarial spleen. J Postrad Med 1992, 38(3):141-142.

57. John BV, Ganesh A, Aggarwal S, Clement E: Persistent hypotension and splenic rupture in a patient with Plasmodium vivax and faciparum co-infection. J Postarad Med 2004, 50(1):80-81.

58. Rubio PA, Berkman NL: Rupture of the spleen in a Central American immigrant. Hosp Pract 1996, 31(1):89-90.

59. Clezy JK, Richens JE: Non-operative management of a spontaneously rupture malarial spleen. Br J Surg 1985, 72:990.

60. Adam I, Adam ES: Spontaneous splenic rupture in a pregnant Sudanese woman with Falciparum malaria: a case report. East Mediter Health J 2007, 13:735-736.

61. Tu AS, Tran MT, Larsen CR: Spontaneous splenic rupture: Report of five cases and a review of the literature. Emerg Radio/ 1997, 4(6):415-418.

62. Ali J: Spontaneous rupture of the spleen in patients with infectious mononucleosis. Can J Surg 1993, 36(1):49-52.

63. Coltheart G, Little JM: Splenectomy: A review of morbidity. ANZ J Surg 1976, 46(1):32-36.

64. Hyun BH, Varga CF, Rubin RJ: Spontaneous and Pathologic Rupture of the Spleen. AMA Arch Surg 1972, 104(5):652-657.

65. McMahon MJ, Lintott JD, Mair WSJ, Lee PWR, Duthie JS: Occult rupture of the spleen. Br J Surg 1977, 64(9):641-643.

66. Alberty R: Surgical implications of infectious mononucleosis. Am J Surg 1981, 141(5):559-561.

67. Badura RA, Oliveira O, Palhano MJ, Borregana J, Quaresma J: Spontaneous rupture of the spleen as presenting even in infectious mononucleosis. Scan J Infec Dis 2001, 33:872-874.

68. Bonsignore A, Grillone G, Soliera M, Fiumara F, Pettinato M, Calarco G, Angio LG, Licursi M: [Occult rupture of the spleen in a patient with infectious mononucleosis] Italian. G Chir 2010, 31(3):86-90.

69. Gauderer MWL, Stellato TA, Hutton MC: Splenic injury: Nonperative management in three patients with infectious mononucleosis. J Pediatr Surg 1989, 24(1):118-120

70. Gayer G, Zandman-Boddard G, Kosych E: Spontaneous rupture of the spleen detected on CT as the initial manifestation of infectious mononucleosis. Emerg Radiol 2003, 10:51.

71. Mavinamane S, Yadava R, Abood E: Spontaneous splenic rupture secondary to infectious mononucleosis [abstract]. Eur J Intern Med 2009, 20:S219-S219. 
72. Patel JM, Rizzolo E, Hinshaw JR: Spontaneous subcapsular splenic hematoma as the only clinical manifestation of infectious mononucleosis. JAMA 1982, 247:3243-3244.

73. Rotolo JE: Spontaneous splenic rupture in infectious mononucleosis. Am J Emerg Med 1987, 5(5):383-385.

74. Stephenson JT, DuBois JJ: Nonoperative management of spontaneous splenic rupture in infectious mononucleosis: A case report and review of the literature. Pediatrics 2007, 120(2):e432-e435.

75. Stockinger ZT: Infectious mononucleosis presenting as spontaneous splenic rupture without other symptoms. Mil Med 2003, 168(9):722-724.

76. Szoko M, Matolcsy A, Kovacs G, Simon G: Spontaneous splenic rupture as a complication of symptom-free infections mononucleosis. Orv Hetil 2007, 148(29):1381-1384.

77. Blaivas M, Quinn J: Diagnosis of spontaneous splenic rupture with emergency ultrasonogrophy. Ann Emerg Med 1998, 32:627-630.

78. Semrau F, Kühl R, Ritter K: Ruptured spleen and autoantibodies to superoxide dismutase in infectious mononucleosis. Lancet 1996, 347(9008):1124-1125.

79. Johnson M, Cooperberg P, Boisvert J, Stoller J, Winrob H: Spontaneous splenic rupture in infectious mononucleosis: sonographic diagnosis and follow-up. Am J Roentgenol 1981, 136(1):111-114.

80. Klinkert P, Kluit AB, Vries AC, Puylaert JBCM: Spontaneous Rupture of the Spleen: Role of Ultrasound in Diagnosis, Treatment, and Monitoring. Eur J Surg 1999, 165(7):712-713.

81. MacGowan JR, Mahendra P, Ager S, Marcus RE: Thrombocytopenia and spontaneous rupture of the spleen associated with infectious mononucleosis. Clin Lab Haematol 1995, 17:93-94.

82. Miranti JP, Rendleman DF: Spontaneous rupture of the spleen as the presenting event in infectious mononucleosis. J Am Coll Health AssoC 1981, 30:96.

83. Gordon MK, Rietveld JA, Frizelle FA: The management of splenic rupture in infetious mononucleosis. Aust N Z J Surg 1995, 65:247-250.

84. Fleming WR: Spontaneous splenic rupture in infectious mononucleosis. Aust N Z J Surg 1991, 61:389-390.

85. Peters RM, Gordon LA: Nonsurgical treatment of splenic hemorrhage in an adult with infectious mononucleosis: Case report and review. Am J Med 1986, 80(1):123-125.

86. Schuler JG, Filtzer H: Spontaneous Splenic Rupture: The Role of Nonoperative Management. Arch Surg 1995, 130(6):662-665.

87. Purkiss SF: Splenic rupture and infectious mononucleosis-splenectomy, splenorrhaphy or non operative management. J R Soc Med 1992, 85 (8):458-459.

88. Aswani V, Visekruna M: Atraumatic splenic rupture (abstract). Wisconsin Med J 2008, 1007:247.

89. Lum D: Infectious mononucleosis. Proc UCLA Healthcare 2005, 9:1-3.

90. Al-Mashat FM, Sibiany AM: Al Amri AM: Spontaneous splenic rupture in infectious mononucleosis. Saudi J Gastroenterol 2003, 9:84-86.

91. Lieberman ME, Levitt MA: Spontaneous rupture of the spleen: A case report and literature review. Am J Emerg Med 1989, 7(1):28-31.

92. Maillard N, Koenig M, Pillet S, Cuilleron M, Cathebras P: Spontaneous splenci rupture in primary cytomegalovirus infections. La Presse Medicale 2007, 36:874-877.

93. Rogues AM, Dupon M, Cales V, Malou M, Paty MC, Le Bail B, Lacut JY: Spontaneous splenic rupture: an uncommon complication of cytomegalovirus infection. J Infect 1994, 29(1):83-85

94. Alliot C, Beets C, Besson M, Derolland P: Spontaneous splenic rupture associated with CMV infection: a report of a case and review. Scand J Infect Dis 2001, 33:875-877.

95. Ragnaud J, Morlat P, Gin H, Dupon M, Delafaye C, du Pasquier P, Aubertin J: Aspects cliniques, biologiques et évolutifs de l'infection à cytomégalovirus chez le sujet immunocompétent: à propos de 34 patients hospitalisés. La Revue de Médecine Interne 1994, 15(1):13-18.

96. Ali G, Kamili MA, Rashid S, Mansoor A, Lone BA, Allaqaband GQ: Spontaneous splenic rupture in typhoid fever. Postgrad Med J 1994, 70(825):513-514

97. Julià J, Canet JJ, Martínez Lacasa X, González G, Garau J: Spontaneous spleen rupture during typhoid fever. Int J Infect Dis 2000, 4(2):108-109.

98. Shivashankar GH, Kelly JF: Spontaneous splenic rupture. Surgery On-line 2007.
99. Winearls JR, McGloughlin S, Fraser JF: Splenic rupture as a presenting feature of endocarditis. Eur J Cardiothorac Surg 2009, 35(4):737-739.

100. Llanwarne N, Badic B, Delugeau V, Landen S: Spontaneous splenic rupture associated with Listeria endocarditis. Am J Emerg Med 2007, 25(9):1086. e3-1086.e5.

101. Casanova-Roman M, Casas J, Sanchez-Porto A, Nacie B: Spontaneous rupture of the spleen associated with Legionella pneumonia. Can J Infect Dis Med Microbiol 2010, 21(3):e107-e108.

102. Saura $P$, Valles J, Jubert $P$, Ormaza J, Sequra F: Spontaneous rupture of the spleen in a patient with legionellosis. Clin Infect Dis 1993, 17(2):298.

103. Athey RJ, Barton LL, Horgan LF, Wood BH: Spontaneous splenic rupture in a patient with pneumonia and sepsis. Acute Medicine 2006, 5:21-23.

104. Barrier JH, Bani-Sadr F, Gaillard F, Raffi F: Spontaneous rupture of the spleen revealing primary human immunodeficiency virus infection. Clin Infect Dis 1997, 25(2):336-337.

105. Mirchandani HG, Mirchandani IH, Pak MSY: Spontaneous rupture of the spleen due to AIDS in an IV drug abuser. Arch Pathol Lab Med 1985, 109:1114-1116.

106. Vallabhaneni S, Scott H, Carter J, Treseler P, Machtinger EL: Atraumatic splenic rupture: an unusual manifestation of acute HIV infection. AIDS Patient Care STDS 2011, 25(8):461-464.

107. Henderson SA, Templeton JL, Wilkinson AJ: Spontaneous splenic rupture: a unique presentation of Q fever. Ulster Med J 1988, 57(2):218-219.

108. Baumbach A, Brehm B, Sauer W, Doller G, Hoffmeister HM: Spontaneous splenic rupture complicating acute Q fever. Am J Gastroenterol 1992, 87 (11):1651-1653.

109. Rest JG, Seid AS, Rogers D, Goldstein EJ: Pathologic rupture of the spleen due to Salmonella dublin infection. J Trauma 1985, 25:366-368.

110. Benanti C, Arena L, Albertacci A, Rosso L: From spontaneous rupture of the spleen to septic shock in a case of salmonellosis. Acta Anaesth Italica 2007, 58:182-194.

111. Lam KY, Ng WF, Chan ACL: Miliary tuberculosis with splenic rupture: A fatal case with hemophagocytic syndrome and possible association with long standing sarcoidosis. Pathology 1994, 26(4):493-493.

112. Pramesh C, Tamhankar A, Rege S, Shah S: Splenic tuberculosis and HIV-1 infection. Lancet 2002, 359(9303):353.

113. Lazaro EJ, Ong F, Parmer LP: Splenic rupture masquerading as acute appendicitis. Am Surg 1970, 36:705-708.

114. Guleria S, Dorairajan LN, Sinha S, Khazanchi R, Bal S, Guleria R: Spontaneous rupture of spleen in viral hepatitis A. Indian J Gastroenterol 1996, 15:30.

115. Fonseca AG, Amaro M, Travancinha D, Barata J: A surprising virus spontaneous spleen rupture presenting EBV infection. Abstract 67.006. Lisbon Portugal: 12th International Congress on Infectious Diseases (ICID); 2006.

116. Tweed J: Tick trauma: tiny insect nearly did in veteran deputy. Brainerd Daily Dispatch 2005, http://lymespot.blogspot.ca/2005_05_01_archive.html.

117. Dulger AC, Yilmaz M, Aytemiz E, Bartin K, Bulut MD, Kemik O, Sumer A: Spontaneous splenic rupture and hemoperitoneum due to brucellosis infection: A case report. Van Tip Dergisi 2011, 18(1):41-44.

118. Daybell D, Paddock CD, Zaki SR, Comer JA, Woodruff D, Hansen KJ, Peacock JE: Disseminated Infection with Bartonella henselae as a Cause of Spontaneous Splenic Rupture. Clin Infect Dis 2004, 39(3):e21-e24.

119. Redondo MC, Rios A, Cohen R, Ayala J, Martinex J, Arellano G, et al: Hemmorhagic dengue with spontaneous splenic rupture: case report and review. Clin Infect Dis 1997, 25:1262-1263.

120. Peiper $M$, Broering DC, Schroter M, Rogiers X: Rupture of the spleen associated with Enterobacter cloacae. Acta Chir Belg 1999, 99:85-86.

121. McKelvey SD, Braidley PC, Stansby GP, Weir WRC: Spontaneous splenic rupture associated with murine typhus. J Infect 1991, 22(3):296-297.

122. Schmulewitz L, Moumile K, Patey-MariousdeSerre N, Poiree S, Gouin E, Mechai F, et al: Splenic rupture and malignant Mediterranean spotted fever. Emerg Infect Dis 2008, 14:995-996.

123. Vial I, Hamidou M, Coste-Burel M, Baron D: Abdominal pain in varicella: an unusual cause of spontaneous splenic rupture. Eur J Emerg Med 2004, 11:176-177.

124. Torricelli P, Coriani C, Marchetti M, Rossi A, Manenti A: Spontaneous rupture of the spleen: Report of two cases. Abdom Imaging 2001, 26(3):290-293.

125. Andrews DF, Hernandez R, Grafton W, Williams DM: Pathologic rupture of the spleen in non-Hodgkin's lymphoma. Arch Intern Med 1980, 140(1):119-120. 
126. Dobashi N, Kuraishi Y, Kobayashi T, Hirano A, Isogai Y, Takagi K: Spontaneous splenic rupture in a case of non-Hodgkin's lymphoma. Rinsho Ketsueki 1993, 34(2):190-193.

127. Haj M, Zaina A, Wiess M, Cohen I, Joseph M, Horn I, Eitan A: Pathologicspontaneous-rupture of the spleen as a presenting sign of splenic T-cell lymphoma - Case report with review. Hepatogastroenterology 1999, 46(25):193-195.

128. Lunning MA, Stetler-Stevenson M, Silberstein PT, Zenger V, Marti GE: Spontaneous (pathological) splenic rupture in a blastic variant of mantle cell lymphoma: A case report and literature review. Clin Lymphoma 2002, 3(2):117-120.

129. Mason KD, Juneja SK: Spontaneous rupture of the spleen as the presenting feature of the blastoid variant of mantle cell lymphoma. Clin Lab Haematol 2003, 25(4):263-265.

130. Opeskin K, Ellis D, Burke M: Anaplastic lymphoma kinase-positive anaplastic large cell lymphoma presenting with spontaneous splenic rupture. Pathology 2004, 36(1):94-96.

131. Salmi R, Guadenzi P, DiTodaro F, Morandi P, Nielsen I, Manfredini R: When a car accident can change the life: Splenic lymphoma and not post-traumatic haematoma. Intern Emerg Med 2008, 3(3):1007-1008.

132. Strickland AH, Marsden KA, McArdle J, Lowenthal RM: Pathologic Splenic Rupture as the Presentation of Mantle Cell Lymphoma. Leuk Lymphoma 2001, 41(1):197.

133. Zieren J, Paul M, Scharfenberg M, Müller JM: The spontaneous splenic rupture as first manifestation of mantle cell lymphoma, a dangerous rarity. Am J Emerg Med 2004, 22(7):629-631.

134. Biswas S, Keddington J, McClanathan J: Large B- cell lymphoma presenting as acute abdominal pain and spontaneous splenic rupture; a case report and review of relevant literature. World J Emerg Surg 2006, 1(1):35.

135. Chen JH, Chan DC, Lee HS, Liu HD, Hsieh CB, Yu JC, Liu YC, Chen CJ: Spontaneous splenic rupture associated with hepatosplenic gammadelta T-cell lymphoma. J Formos Med Assoc 2005, 104(8):593-596.

136. Narasimhan P, Hitti IF, Gheewala P, Pulakhandam U, Kanzer B: Unusual presentations of lymphoma: Case 3. Splenic hematoma associated with non-Hodgkin's lymphoma. J Clin Oncol 2002, 20:1946-1947.

137. Thomson WHF: Diffuse lymphocytic lymphoma with splenic rupture. Postgrad Med J 1969, 45:50-51.

138. Chappuis J, Simoens C, Smets D, Duttmann R, Mendes da Costa P: Spontaneous rupture of the spleen in relation to a non-Hodgkin lymphona. Acta Chir Belg 2007, 107:446-448.

139. Hebeda KM, MacKenzie MA, van Krieken JH: A case of anaplastic lymphoma kinase-positive anaplastic large cell lymphoma presenting with spontaneous splenic rupture: an extremely unusual presentation. Virchows Arch 2000, 437:459-464.

140. Soria-Aledo V, Aguilar-Domingo M, Garcia-Cuadrado J, Carrasco-Prats M, Gonzalez-Martinez P: Spontaneous rupture of the spleen: a rare form of onset of non-Hodgkin's lymphoma. Rev Clin Esp 1999, 199:552-553.

141. Roncella S, Cutrona G, Truini M, Airoldi I, Pezzolo A, Valetto A, Di Martino D, Dadati P, De Rossi A, Ulivi M, Fontana I, Nocera A, Valente U, Ferrarini M, Pistoia V: Late Epstein-Barr virus infection of a hepatosplenic gamma delta T-cell lymphoma arising in a kidney transplant recipient. Haematologica 2000, 85(3):256-262.

142. Tanaka M, Minato T, Yamamura Y, Katayama K, Ishikura H, Ichimori T, et al: A case of non-Hodgkin Lymphoma presenting with spontaneous splenic rupture. Tokushima Red Cross Hospital Medical Journal 2008, 13:91-95.

143. Matsui H, Andou S, Sakakibara K, Tsuji H, Uragami T, Karamatsu S, et al: A case of spontaneous splenic rupture due to malignant lymphoma. Jpn J Gastroenterol Surg 1994, 27:2166-2170.

144. Fausel R, Sun NCJ, Klein S: Splenic rupture in a human immunodeficiency virus-infected patient with primary splenic lymphoma. Cancer 1990, 66(44):2414-2416.

145. Hoar FJ, Chan S, Stonelake PS, Wolverson RW, Bareford D: Splenic rupture as a consequence of dual malignant pathology: a case report. $J$ Clin Pathol 2003, 56(9):709-710.

146. Brissette M, Dhru RD: Hodgkin's disease presenting as spontaneous splenic rupture. Arch Pathol Lab Med 1992, 116(10):1077-1079.

147. Dobrow RB: Spontaneous (pathologic) rupture of the spleen in previously undiagnosed Hodgkin's disease. Report of a case with survival. Cancer 1977, 39(1):354-358.
148. Saba HI, Garcia W, Hartmann RC: Spontaneous ruptur eof the spleen: an unusual presenting feature in Hodgkin's lymphoma. South Med J 1983, 76:247-249

149. Bloom RA, Freund V, Perkes EH, et al: Acute Hodgkin's disease masquerading as splenic abscess. J Surg Oncol 1981, 17:279-282.

150. Beshara FM: Spontaneous rupture of the spleen in Hodgkin's lymphoma. Clin Oncol 1982, 8:69-71.

151. Amonkar SJ, Kumar EN: Spontaneous rupture of the spleen: three case reports and causative processes for the radiologist to consider. $\mathrm{Br} J$ Radiol 2009, 82:e111-e113.

152. Berrebi A, Bustan A, Mashiah A, Hurwitz N: Splenic rupture as a presenting sign of lymphoma of the spleen. Isr J Med Sci 1984, 20(1):66-67.

153. Chow MS, Taylor MA, William Hanson C III: Splenic laceration associated with transesophageal echocardiography. J Cardiothorac Vasc Anesth 1998, 12(3):314-316.

154. Rhee SJ, Sheena Y, Imber C: Spontaneous rupture of the spleen: a rare but important differential of an acute abdomen. Am J Emerg Med 2008, 26(6):733. e5-733.e6.

155. Altes A, Brunet S, Martinez C, Soler J, Ayats R, Sureda A, Lopez R, Domingo A: Spontaneous splenic rupture as the initial manifestation of acute lymphoblastic leukaemia: Immunophenotype and cytogenetics. Ann Hematol 1994, 68(3):143-144.

156. Banerjee PK, Bhansali A, Dash S, Dash RJ: Acute lymphoblastic leukaemia manifesting with splenic rupture. J Assoc Physicians India 1990, 38(6):434-435.

157. Bernat S, Garcia-Boyero R, Guinot M, Lopez F, Gozalbo T, Canigral G: Pathologic rupture of the spleen as the initial manifestation in acute lymphoblastic leukemia. Haematalogica 1998, 83:760-761.

158. Gibbs TJ, Sells RA, Bellingham AJ: A rare presentation of splenic rupture. Postgrad Med J 1977, 53(621):403-405.

159. Johnson CS, Rosen PJ, Sheehan WW: Acute lymphocytic leukemia manifesting as splenic rupture. Am J Clin Pathol 1979, 72(1):118-121.

160. McEntee GP, Duignan JP, Otridge BW, Heffeman SJ: Acute lymphocytic leukaemia presenting as spontaneous splenic rupture. I J M S 1984 153(8):284-285.

161. Donfrid M, Trisic B, Kraguljac N, Cemerikic V, Suvajdzic N, Colovic M: Subcapsular splenic hematoma as the initial manifestation of gammadelta + T-cell acute lymphoblastic leukaemia. Haema 2001, 4:49-51.

162. Narang M, Sunita SS, Bhasin S, Sharma M, Gupta DK: Spontaneous splenic rupture - A rare initial manifestation of acute lymphoblastic leukemia. Ind J Med Paediatr Oncol 2005, 26:68-70.

163. Gorosquieta A, Pérez-Equiza E, Gastearena J: [Asymptomatic pathological rupture of the spleen as the presenting form of acute lymphoblastic leukemia. Sangre (Barc) 1996, 41:261-262.

164. Rodriguez-Luaces M, Jimenez HC, Lafuente GA, Mateos RP, Hernandez-Bajo $J M$ : Pathological ruptue of the spleen as the initial manifestation of acute lymphoblastic leukemia. Haematologica 1998, 83:383-384.

165. Carrasco CD, Yin JL: Spontaneous rupture of the spleen in a patient with B-cell acute lymphoblastic leukaemia. Ann Hematol 2005, 84:555-556.

166. Leuridan B, Sigam M, Callens J, Langeron P: Spontaneous rupture of the spleen revealing a chronic myeloid leukemia. J Sci Med Lille 1970, 88(10):537-541.

167. Loza J, Egurbide I, Ramirez G: Spontaneous spleen rupture as presenting feature and cause of death in chronic myelogenous leukaemia. Sangre 1979, 24(1):73-79.

168. Pelosi AJ, Sinclair DJM: Spontaneous rupture of the spleen as the presenting feature of chronic myeloid leukemia. Scott Med J 1981, 26(4):352-353.

169. Nestok BR, Goldstein JD, Lipkovic P: Splenic rupture as a cause of sudden death in undiagnosed chronic myelogenous leukemia. Am J Forensic Med Pathol 1988, 9(3):241-245.

170. Wang JY, Lin YF, Lin SH, Tsao TY: Hemoperitoneum due to splenic rupture in a CAPD patient with chronic myelogenous leukemia. Perit Dial Int 1998, 18:334-337.

171. Marcos-Sánchez F, Juárez-Ucelay F, Aparicio-Martínez JC, Durán-Pérez NA: Stress angina, spontaneous rupture of the spleen and almost normal leukocyte values, a rare form of presentation of chronic myeloid leukosis. An Med Interna 1991, 8:575-576.

172. Diebold J, Audoin J: Peliosis of the spleen. Report of a case associated with chronic myelomonocytic leukemia, presenting with spontaneous 
splenic rupture. Am J Surg Pathol 1983, 7:197-204.

173. Han J, Oh SY, Kim S, Kwon H, Hong SH, Han JY, Park K, Kim H: A case of pathologic splenic rupture as the initial manifestation of acute myeloid leukemia M2. Yonsei Med J 2010, 51(1):138-140.

174. Rajagopal A, Rmasamy R, Martin J: Acute myeloid leukemia presenting as splenic rupture. J Assoc Physicians India 2002, 50:1435-1437.

175. Serur D, Terjanian T: Spontaneous rupture of the spleen as the initial manifestation of acute myeloid leukemia. N Y State J Med 1992, 92:160-161.

176. Tan A, Ziari M, Salman H, Ortega W, Cortese C: Spontaneous rupture of the spleen in the presentation of Acute Myeloid Leukemia. J Clin Oncol 2007, 25(34):5519-5520.

177. Sonobe H, Uchida H, Doi K, Shinozaki Y, Kunitomo T, Ogawa K: Spontaneous rupture of the spleen in acute myeloid leukemia. Acto Pathol Jpn 1981, 31(2):309-318.

178. Nagarsheth KH, Tucker B, Taylor D: Non-traumatic splenic rupture disguised as fall injury. Internet J Surg 2010, 24(1):5p-5p.

179. Joubaud F, Gardais J, D'Aubigny N, Saint-Andre JP: Spontaneous rupture of the spleen in a patient with hairy cell leukemia. Semaine des Hopitaux 1985, 61(20):1449-1451.

180. Von Der Walde J, Mashiah A, Berrebi A: Tumores rari et inusitati. Spontaneous rupture of the spleen in hairy cell leukemia. Clin Oncol 1981, 7(3):241-244

181. Ustün C, Sungur C, Akbas O, Sungur A, Gürgen Y, Ruacan S, et al: Spontaneous splenic rupture as the initial presentation of plasma cell leukemia: a case report. Am J Hematol 1998, 57:266-267.

182. Morla J, Masa L, Antela C, Barrio E: [Spontaneous rupture of the spleen as the form of presentation of hairy cell leukemia]. Med Clin (Barc) 1991, 96:198.

183. Minato E, Fujino I, Sugihira N, Matsumoto K, Shima K, Miki C: Spontaneous Splenic Rupture in a Case of Adult T Cell Leukemia. Jpn J Gastroenterol Surg 2003, 36(11):1571-1574.

184. Saiers JH: Acute leukemia presenting as a ruptured spleen. Report of a case. Rocky Mt Med J 1977, 74:319-320.

185. Low SE, Stafford JS: Malignant histiocytosis: a case report of a rare tumour presenting with spontaneous splenic rupture. J Clin Pathol 2006, 59:770-772.

186. de Lajarte-Thirouard AS, Molina T, Audoin J, Le Tourneau A, Leduc F, Rose C, et al: Spleen localization of light chain deposition disease associated with sea blue histiocytosis, revealed by spontaneous rupture. Virchows Arch 1999, 434:463-465.

187. Gonday G, Delluc G, Demoures A: [Sea blue histiocyte syndrome. Disclosure by spontaneous splenic rupture. Nouv Presse Med 1982, 11:1949.

188. Dawson PJ, Dawson G: Adult niemann-pick disease with sea-blue histiocytes in the spleen. Hum Pathol 1982, 13(12):1115-1120.

189. Wilson Cl, Cabello-Inchausti B, Sendzischew H, Robinson MJ: Ceroid histiocytosis: an unusual cause of traumatic splenic rupture. South Med J 2001, 94:237-239.

190. Rodon P, Ramain JP, Bruandet P, Piedon A, Akli J, Penot J: La maladie de Niemann-Pick type B avec syndrome des histiocytes bleu de mer. La Revue de Médecine Interne 1991, 12(4):299-302.

191. Sherwood P, Sommers A, Shirfield M, Majumdar G: Spontaneous splenic rupture in uncomplicated multiple myeloma. Leuk Lymphoma 1996, 20(5-6):517-519.

192. Levy J: Spontaneous rupture of the spleen in association with idiopathic thrombocytopaenic purpura. Postarad Med J 1994, 70:239.

193. Sawlani KK, Gaiha M, Jain S, Shome DK, Aggarwal SB, Rani S, et al: Rare presentations of idiopathic myelofibrosis: spontaneous rupture of the spleen; pyoderma gangrenosum; and urologic obstruction. J Assoc Physicians India 1998, 46:230-232.

194. Friedrich EB, Kindermann M, Link A, Böhm M: Splenic rupture complicating periinterventional glycoprotein IIb/Illa antagonist therapy for myocardial infarction in polycythemia vera. Z Kardiol 2005, 94(3):200-204.

195. Sharma D: Sub-capsular splenectomy for delayed spontaneous splenic rupture in a case of sickle cell anemia. World J Emergency Surgery 2009, 4(1):17.

196. Chim CS, Kwong YL, Shek TW, Ma SK, Ooi GC: Splenic rupture as the presenting symptom of blastic crisis in a patient with Philadelphia-negative, bcr-abl-positive ET. Am J Hematol 2001, 66(1):70-71.

197. Franssen CFM, Ter Maaten JC, Hoorntje SJ: Spontaneous splenic rupture in Wegener's vasculitis. Annals of Rheumatic Disease 1993, 52:314.
198. Hawley PH, Copland G, Zetler P: Spontaneous splenic rupture in c-ANCA positive vasculitis. Aust N Z J Medicine 1996, 26:431-432.

199. McCain M, Quinet R, Davis W, Serebro L, Zakem J, Nair P, Ishaq S: Splenic rupture as the presenting manifestation of vasculitis. Semin Arthritis Rheum 2002, 31(5):311-316

200. Fallingborg J, Lausten J, Winther P, Svanholm H: Atraumatic rupture of the spleen in periarteritis nodosa. Acta Chir Scand 1985, 151(1):85-87.

201. Ford GA, Bradley JR, Appleton DS: Spontaneous splenic rupture in polyarteritis nodosa. Postgrad Med J 1986, 62(732):965-966.

202. Tolaymat A, Al-Mousily F, Haafiz AB, Lammert N, Afshari S: Spontaneous rupture of the spleen in a patient with systemic lupus erythematosus. J Rheumatol 1995, 22:2344-2345.

203. Zimmerman-Gorska I, Bielaka K: Splenic rupture in the course of SLE. Pol Tyr Lek 1971, 26:1991-1992.

204. Van de Voorde K, De Raeve H, De Block CE, Van Regenmortel N, Van Offel JF, De Clerck LS, Stevens WJ: Atypical systemic lupus erythematosus or Castleman's Disease. Act Clin Belg 2004, 59:161-164.

205. Pena JM, Garcia-Alegria J, Crespo M, Gijon J, Vazquez JJ: Spontaneous rupture of the spleen in rheumatoid arthritis. Ann Rheum Dis 1984, 43:539.

206. Orloff MJ, Peskin GW: Spontaneous rupture of the normal spleen; a surgical enigma. Int Abstr Surg 1958, 106(1):1-11.

207. Cubo T, Ramia JM, Pardo R, Martin J, Padilla D, Hernandez-Calvo J: Spontaneous rupture of the spleen in amyloidosis. Am J Emerg Med 1997, 15(4):443-444.

208. Gupta R, Singh G, Bose SM, Vaiphei K, Radotra B: Spontaneous rupture of the amyloid spleen: a report of two cases. J Clin Gastroenterol 1998, 26:161.

209. Oran B, Wright DG, Seldin DC, McAneny D, Skinner M, Sanchorawala V: Spontaneous rupture of the spleen in AL amyloidosis. Am J Hematol 2003, 74:131-135.

210. Hurd WW, Katholi RE: Acquired Functional Asplenia: Association With Spontaneous Rupture of the Spleen and Fatal Spontaneous Rupture of the Liver in Amyloidosis. Arch Intern Med 1980, 140(6):844-845.

211. Nowak G, Westermark P, Wernerson A, Herlenius G, Sletten K, Ericzon BG: Liver transplantation as rescue treatment in a patient with primary $\mathrm{AL}$ kappa amyloidosis. Transpl Int 2000, 13:92-97.

212. Okazaki K, Moriyasu F, Shiomura T, Yamamoto T, Suzaki T, Kanematsu Y, Akasaka S, Kobashi Y: Spontaneous rupture of the spleen and liver in amyloidosis - a case report and review of the literature. Gastroenterol Jpn 1986, 21(5):518-524.

213. Mumford AD, O'Donnell J, Gillmore JD, Manning RA, Hawkins PN, Laffan M: Bleeding symptoms and coagulation abnormalities in 337 patients with AL-amylodosis. Br J Haematol 2000, 110:454-460.

214. Choufani EB, Sanchorawala V, Ernst T, Quillen K, Skinner M, Wright DG, Seldin DC: Acquired factor $X$ deficiency in patients with amyloid lightchain amyloidosis: incidence, bleeding manifestations, and response to high-dose chemotherapy. Blood 2001, 97(6):1885-1887.

215. Tamarit Garcia JJ, Boluda Garcia F, Calvo Catala J, Campos Fernandez C, Parra Rodenas JV, Gonzalez Cruz ME, et al: [Spontaneous splenic rupture as an unusual presentation of primary amylodiosis. Rev Esp Enferm Dig 1999, 91:653-654.

216. Roll GR, Lee AY, Royaie K, Visser B, Hanks DK, Knudson MM, Roll FJ: Acquired $A$ amyloidosis from injection drug use presenting with atraumatic splenic rupture in a hospitalized patient: a case report. J Med Case Reports 2011, 5(1):29.

217. Rege JD, Kavishwar VS, Mopkar PS: Peliosis of spleen presenting as splenic rupture with haemoperitoneum-a case report. Indian J Pathol Microbiol 1998, 41(4):465-467.

218. Etzion Y, Benharroch D, Saidel M, Riesenberg K, Gilad J, Schlaeffer F: Atraumatic rupture of the spleen associated with hemophagocytic syndrome and isolated splenic peliosis. Case report. APMIS 2005, 113:555-557.

219. Celebrezze JPJ, Cottrell DJ, William GB: Spontaneous splenic rupture due to isolated splenic peliosis. Sout Med J 1998, 91:763-764.

220. Parsons MA, Platts M, Slater D, Fox M: Splenic peliosis associated with rupture in a renal transplant patient. Postgrad Med J 1980 56(661):796-797.

221. Tsokos M, Puschel J: Isolated peliosis of the spleen: report of 2 autopsy cases. Am J Forensic Med Pathol 2004, 25:251-254. 
222. Lashbrook D, James R, Phillips A, Holbrook A, Agombar A: Splenic peliosis with spontaneous splenic rupture: report of two cases. BMC Surg 2006, 6(1):9.

223. Kohr RM, Haendiges M, Taube RR: Peliosis of the spleen: a rare cause of spontaneous splenic rupture with surgical implications. Am Surg 1993, 59:197-199.

224. Hakoda S, Shinya H, Kiuchi S: Spontaneous splenic rupture caused by splenic peliosis of a hemodialysis patient with chronic renal failure receiving erythropoietin. Am J Emerg Med 2008, 26(1):109. e1-109.e2.

225. Dennehy T, Lamphier TA, Wickman W, Goldberg R: Traumatic rupture of the normal spleen: Analysis of eighty-three cases. Am J Surg 1961, 102(1):58-65.

226. Moore PG, Gillies JG, James OF, Saltos N: Occult ruptured spleen-two unusual clinical presentations. Postgrad Med J 1984, 60(700):171-173.

227. Lloyd TV, Johnson JC: Intramural gastric hematoma secondary to splenic rupture. South Med J 1980, 73:1675-1676.

228. Mujtaba G, Josmi J, Arya M, Anand S: Spontaneous splenic rupture: A rare complication of acute pancreatitis in a patient with Crohn's disease. Case Rep Gastroenterol 2011, 5:179-182.

229. Ahmed A, Feller ER: Rupture of the spleen as the initial manifestation of Wilson's disease. Am J Gastroenterol 1996, 91:1454-1455.

230. Holt S: Spontaneous rupture of a normal spleen diagnosed as ruptured ectopic pregnancy. Two case reports. Br J Obstet Gynaecol 1982, 89(12):1062-1063.

231. Lam CM, Yuen ST, Yuen WK: Hemoperitoneum caused by spontaneous rupture of a true splenic cyst. Hepatogastroenterology 1998, 45:1884-1886.

232. Bhagrath R, Bearn P, Sanusi FA, Najjar S, Qureshi R, Simanovitz A: Postpartum rupture of the spleen. Br J Obstet Gynaecol 1993, 100:954-955.

233. Paravastu SC, Burdge A, da Silva A: Spontaneous splenic rupture in the postpartum period. Br J Hosp Med 2008, 69(2):106-107.

234. Kianmanesh $\mathrm{R}$, Aguirre $H \mathrm{H}$, Enjaume $F$, Valverde $A$, Brugière $O$, Vacher $B$, Bleichner G: Ruptures non traumatiques de la rate: trois nouveaux cas et revue de la littérature. Spontaneous splenic rupture: report of three new cases and review of the literature. Ann Chir 2003, 128(5):303-309.

235. Foley WJ, Thompson NW, Herlocher JE, Campbell DA: Occult rupture of the spleen. Surg Gynecol Obstet 1969, 128(6):1215-1220.

236. Mahesh B, Muwanga CL: Splenic infarct: a rare cause of spontaneous rupture leading to massive haemoperitoneum. ANZ J Surg 2004, 74:1030-1032

237. Gascón A, Iglesias E, Bélvis JJ, Berisa F: The elderly haemodialysis patient with abdominal symptoms and hypovolemic shock splenic rupture secondary to splenic infarction in a patient with severe atherosclerosis. Nephrol Dial Transplant 1999, 14:1044-1045.

238. Kanagasundaram NS, Macdougall IC, Turney JH: Massive haemoperitoneum due to rupture of splenic infarct during CAPD. Nephrol Dial Transplant 1998, 13(9):2380-2381.

239. Morgenstern L, McCafferty I, Rosenberg J, Michel SL: Hamartomas of the spleen. Arch Surg 1984, 119:1291-1293.

240. Yoshizawa J, Mizuno R, Yoshida T, Kanai M, Kurobe M, Yamazaki Y: Spontaneous rupture of splenic hamartoma: A case report. J Pediatr Surg 1999, 34(3):498-499.

241. Seyama Y, Tanaka N, Suzuki Y, Nagai M, Furuya T, Nomura Y, et al: Spontaneous rupture of splenic hamartoma in a patient with hepatitis $C$ virus-related cirrhosis and portal hypertension: $A$ case report and review of the literature. World J Gastroenterol 2006, 12(13):2133-2135.

242. Ballardini $P$, Incasa E, Del Noce A, Cavazzini L, Martoni A, Piana E: Spontaneous splenic rupture after the start of lung cancer chemotherapy. A case report. Tumori 2004, 90:144-146.

243. Foiada M, Muller W, Conti Rossini B, Pedrinis E: [Case report of spontaneous splenic rupture in splenoma]. Helv Chir Acta 1993, 60:187-190.

244. Kesava-Rao RC G, Sawhney S, Berry M: Hemangioma of spleen with spontaneous, extra-peritoneal rupture, with associated splenic tuberculosis - an unusual presentation. Australas Radiol 1993, 37(1):100-101.

245. Norris PM, Hughes SCA, Strachan CJL: Spontaneous Rupture of a Benign Cavernous Haemangioma of the Spleen Following Thrombolysis. Eur J Vasc Endovasc Surg 2003, 25(5):476-477.

246. Neumann J, Ambrosius C, Zirngibl H: Spontaneous splenic rupture with diffused angiomatosis of the spleen. Chirurg 1999, 70(7):800-802.
247. Patel VG, Eltayeb OM, Zakaria M, Fortson JK, Weaver WL: Spontaneous Subcapsular Splenic Hematoma: A Rare Complication of Pancreatitis. Am Surg 2005, 71(12):1066-1069.

248. McMahon NG, Norwood SH, Silva JS: Pancreatic pseudocyst with splenic involvement: an uncommon complication of pancreatitis. South Med J 1988, 81:910-912.

249. Drapanas T, Yates AJ, Brickman R, Wholey M: The Syndrome of Occult Rupture of the Spleen. AMA Arch Surg 1969, 99(3):298-306.

250. Williams N, Gerrand C, London NJ, Chapman C, Bell PR: Splenic rupture following splenic vein thrombosis in a man with protein $S$ deficiency. Postgrad Med J 1992, 68(805):928-929.

251. Windham TC, Risin SA, Tamm EP: Spontaneous Rupture of a Nontraumatic Intrasplenic Aneurysm. N Engl J Med 2000, 342(26):1999-2000.

252. Mayo P: Spontaneous rupture of the spleen presenting as acute thoracic empyema. South Med J 1984, 77:1061-1062

253. Paulvannan S, Pye JK: Spontaneous rupture of a normal spleen. Int J Clin Pract 2003, 57(3):245-246.

254. Wisniewski B, Vadrot J, D'Hubert E, Drouhin F, Fischer D, Denis J, Labayle D: Rupture spontanée de rate secondaire à une maladie des embolies de cristaux de cholestérol: à propos d'un cas. Gastroenterol Clin Biol 2004, 28(10, Part 1):922-924

255. Spearman J, Alwan MH: Atraumatic rupture of the spleen: a cautionary note. ANZ J Surg 2006, 76(5):419-421.

256. Robb BW, Reed MF: Congenital diaghragmatic hernia presenting as splenic rupture in an adult. Ann Thorac Surg 2006, 81:e9-e10.

257. Lamerton AJ: Spontaneous rupture of the spleen in early pregnancy. Postgrad Med J 1983, 59(695):596-597.

258. Weekes LR: Ruptured spleen as a differential diagnosis in ruptured tubal pregnancy. J Natl Med Assoc 1984, 76:345-349.

259. Buchsbaum HJ: Splenic rupture in pregnancy: report of a case and review of the literature. Obstet Gynecol Sun 1967, 22:381-395.

260. Barnett $T$ : Rupture of the spleen in pregnancy: a review of recorded cases with a further case report. J Obstet Gynaecol Br Emp 1952, 59:795-802.

261. Gilbert CRA, Goldzieher JW, Cook TA: Insidious rupture of the spleen or splenic vessels associated with pregnancy. J Abdom Surg 1964, 6:48-57.

262. Hunter RM, Shoemaker WC: Rupture of the spleen in pregnancy: a review of the subject and a case report. Am J Obstet Gynecol 1957, 73:1326-1332.

263. Nanda S, Gulati N, Sangwan K: Spontaneous splenic rupture in early pregnancy. Int J Gynaecol Obstet 1990, 31:171-173.

264. O'Brien SE: Spontaneous rupture of the spleen in pregnancy. Can Med Assoc J 1963, 89(13):667-668.

265. Cobellis L, Stradella L, Pecori E, Cobellis G: Spontaneous rupture of the spleen in pregnancy. Minerva Ginecol 2003, 55:289-290.

266. Brocas $E$, Tenaillon A: Spontaneous splenic rupture in the second quarter of pregnancy. Ann Fr Anesth Reanim 2002, 21:231-234.

267. Landa Aranzabal MA, Tubia Landaberea Jl, Esteban Aldezabal L, Carbajal Cervino C, Berdejo Lambarri L: Rotura espontanea de bazo. Presentacion de un caso registrado en una gestante. Cir Esp 1991, 49:459-460.

268. Fletcher H, Frederick J, Barned H, Lizarraga V: Spontaneous rupture of the spleen in pregnancy with splenic conservation. West Indian Med J 1989, 38:114-115.

269. de Graaff J, Pijpers PM: Spontaneous rupture of the spleen in third trimester of pregnancy. Eur J Obstet Gynecol Reprod Biol 1987, 25:243-247.

270. Kiran G, Himsweta S: Spontaneous splenic rupture in pregnancy - a rare entity. J Obstet Gynecol India 2007, 57:545-546.

271. Thakkar U: Spontaneous rupture of spleen. Med J Zambia 1981, 15(2):32-34

272. Bljajić D, Ivanisević M, Djelmis J, Majerović M, Starcević V: Splenic rupture in pregnancy - traumatic or spontaneous event? Eur J Obstet Gynecol Reprod Biol 2004, 115:113-114

273. Popli K, Chitra R, Puri M: Spontaneous rupture of spleen in term pregnancy. Trop Doct 2004, 34:54-55.

274. Epstein M, King R, Kenney D: Splenic rupture at term. Case report. Mo Med 1983, 80:83-84.

275. Londero F, Cociancich G: Spontaneous rupture of the spleen in labor. Am J Obstet Gynecol 2000, 183:782-783

276. Touré B, Ouattara T, Ouédraogo A, Ouédraogo CMR, Koné B: [Splenic rupture during delivery. A case report. Journal Européen des Urgences 2004, 17:87-89. 
277. Denehy T, McGrath EW, Breen JL: Splenic torsion and rupture in pregnancy. Obstet Gynecol Surv 1988, 43(3):123-131.

278. Sparkman RS: Rupture of the spleen in pregnancy. Am J Obst and Gynecol 1958, 76:587-598.

279. Huber DE, Martin SD, Orlay G: A case report of splenic pregnancy. Aust N Z J Surgery 1984, 54:81-82.

280. Michaud P, Robillot P, Tescher M: Spontaneous rupture of the spleen in relation to a splenic pregnancy. Apropos of a case. Rev Fr Gynecol Obstet 1988, 83:281-282.

281. Kalof AN, Fuller B, Harmon M: Splenic pregnancy. A case report and review of the literature. Arch Pathol Lab Med 2004, 128:e146-e148.

282. Caruso V, Hall WH: Primary abdominal pregnancy in the spleen: a case report. Pathology 1984, 16:93-94.

283. Reddy KSP, Modgill VK: Intraperitoneal bleeding due to primary splenic pregnancy. Br J Surg 1983, 70:564.

284. Larkin JK, Garcia DM, Paulson EL, Powers DW: Primary splenic pregnancy with intraperitoneal bleeding and shock: a case report. lowa Med 1988, 78:529-530

285. Yackel DB, Panton ON, Martin DJ, Lee D: Splenic pregnancy - a case report. Obstet Gynecol 1988, 71:471-473.

286. Kahn JA, Skjeldestad FE, Düring V, Sunde A, Molne K, Jørgensen OG: A spleen pregnancy. Acta Obstet Gynecol Scand 1989, 68:83-84.

287. Cormio G, Santamato S, Vimercati A, Selvaggi L: Primary splenic pregnancy. A case report. J Reprod Med 2003, 48:479-481.

288. Sakhel K, Aswad N, Usta I, Nassar A: Postpartum splenic rupture. Obstet Gynecol 2003, 102:1207-1210.

289. McCormick GM, Young DB: Spontaneous rupture of the spleen. A fatal complication of pregnancy. Am J Forensic Med Pathol 1995, 16:132-134

290. Kaluarachchi A, Krishnamurthy S: Post-cesarean section splenic rupture. Am J Obstet Gynecol 1995, 173:230-232.

291. Huang YH, Hsu CY, Chang YF, Chen CP: Postcesarean splenic torsion. Taiwan J Obstet Gynecol 2006, 45:257-259.

292. Barrilleaux PS, Adair D, Johnson G, Lewis DF: Splenic rupture associated with severe preeclampsia. A case report. J Reprod Medicine 1999, 44:899-901.

293. Manda P, Dorman E, Olagbaiye F, Akinfenwa O: A case report of spontaneous splenic capsular rupture associated with atypical presentation of haemolysis, elevated liver enzymes, low platelet count (HELLP) syndrome. J Obstet Gynaecol 2004, 24(3):317-318.

294. Maier A, Bataille F, Krenz D, Anthuber M: Angiosarcoma as a rare differential diagnosis in spontaneous rupture of the spleen. Der Chirurg 2004, 75:70-74.

295. Miyata T, Fujimoto Y, Fukushima M, Torisu M, Tanaka M: Spontaneous rupture of splenic angiosarcoma: A case report of chemotherapeutic approach and review of the literature. Surg Today 1993, 23:370-374.

296. Aranha GV, Gold J, Grage TB: Hemangiosarcoma of the spleen: report of a case and review of previously reported cases. J Surg Oncol 1976, 8:481-487.

297. Reale A, Petrogalli F: Hemangiosarcome of the spleen. Report of a case. Pathologica 1996, 88(1):49-51

298. Simanski DA, Schiby G, Dreznik Z, Jacob ET: Rapid progressive dissemination of hemangiosarcoma of the spleen following spontaneous rupture. World J Surg 1986, 10(1):142-145.

299. Sivelli R, Piccolo D, Soliani P, Franzini C, Ziegler S, Sianesi M: Rupture of the spleen in angiosarcoma: a case report and review of the literature. Chir Ital 2005, 57:377-380.

300. Wick MR, Scheithauer BW, Smith SL, Beart RWJ: Primary nonlymphoreticular malignant neoplasms of the spleen. Am J Surg Pathol 1982, 6:229-242

301. Winde G, Sprakel B, Bosse A, Reers B, Wendt M: Rupture of the spleen caused by primary angiosarcoma. Case report. Acta Chir Eur J Surg 1991 157(3):215-217.

302. Villedieu Poignant $S$, Mermet $L$, Bousquet A, Dupont P: Une cause rare d'hémopéritoine spontané. La Revue de Médecine Interne 2000, 21(9):809-811.

303. Safarpor D, Safapor F, Aghajanzade M, Kohsari M, Hoda S: Spontaneous rupture of the spleen: A case report and review of the literature. Saudi J Gastroenterol 2007, 13(3):136-137.

304. Falk S, Krishnan J, Meis JM: Primary angiosarcoma of the spleen. A clinicopathologic study of 40 cases. Am J Surg Pathol 1993, 17:959-970.
305. Hsu JT, Chen HM, Lin CY, Yeh CN, Hwang TL, Jan YY, et al: Primary angiosarcoma of the spleen. J Surg Oncol 2005, 92:312-316.

306. Neuhauser TS, Derringer GA, Thompson LD, Fanburg-Smith JC, Miettinen M, Saaristo A, et al: Splenic angiosarcoma: a clinicopathologic and immunophenotypic study of 28 cases. Mod Pathol 2000, 13:978-987.

307. Mahony B, Jeffrey RB, Federle MP: Spontaneous rupture of the hepatic and splenic angiosarcoma demonstrated by CT. Am J Roentgenol 1983 138:965-966.

308. Thompson WM, Levy AD, Aguilera NS, Gorospe L, Abbott RM: Angiosarcoma of the Spleen: Imaging Characteristics in 12 Patients. Radiology 2005, 235(1):106-115.

309. Catalano O, Sandomenico F, Raso MM, Siani A: Real-time, contrastenhanced sonography: A new tool for detecting active bleeding. J Trauma 2005, 59:933-939.

310. Kristoffersson A, Emdin S, Jarhult J: Acute intestinal obstruction and splenic hemmorrhage due to metastatic choriocarcinoma. A case report. Acta Chir 1985, 454:381-384.

311. Ghinescu C, Sallami Z, Jackson D: Choriocarcinoma of the spleen - a rare cause of atraumatic rupture. Ann R Coll Surg Engl 2008, 90:W12-W14.

312. Hou HC, Chen CJ, Chang TC, Hsieh TT: Metastatic choriocarcinoma with spontaneous splenic rupture following term pregnancy: a case report. Changgeng Yi Xue Za Zhi 1996, 19:166-170.

313. Lam KY, Tang V: Metastatic Tumors to the Spleen. Arch Pathol Lab Med 2000, 124(4):526-530.

314. Challis DE, Rew KJ, Steigrad SJ: Choriocarcinoma complicated by splenic rupture: an unusual presentation. J Obstet Gynaecol Res 1996, 22:395-400.

315. Giannakopoulos G, Nair S, Snider PS, Amenta C: Implications for the pathogenesis of aneurysm formation: Metastatic choriocarcinoma with spontaneous splenic rupture. Case report and a review. Surg Neurol 1992, 38(3):236-240

316. Smith WM, Lucas JG, Frankel WL: Splenic rupture: A rare presentation of pancreatic carcinoma. Arch Pathol Lab Med 2004, 128(10):1146-1150.

317. Chung S, Park K, Li AK: A pancreatic tumour presenting as a ruptured spleen. HPB Surg 1989, 1:161-163.

318. Patrinou V, Skroubis G, Zolota V, Vagianos C: Unusual presentation of pancreatic mucinous cystadenocarcinoma by spontaneous splenic rupture. Dig Surg 2000, 17:645-647

319. Yettimis E, Trompetas V, Varsamidakis N, Courcoutsakis N, Polymeropoulos V Kalokairinos E: Pathologic splenic rupture. An unusual presentation of pancreatic cancer. Pancreas 2003, 27:273-274.

320. Otero-Palleiro MM, Barbagelata-Lopez C: Spontaneous rupture of the spleen: a rare form of onset gastric carcinoma]. Med Clin (Barc) 2006, $127: 318$

321. Gupta PB, Harvey L: Spontaneous rupture of the spleen secondary to metastatic carcinoma. Br J Surg 1993, 80:613.

322. Lachachi F, Abita T, Durand Fontanier S, Maisonnette F, Descottes B: Spontaneous splenic rupture due to splenic metastasis of lung cancer. Ann Chir 2004, 129:521-522.

323. Kyriacou A, Arulraj N, Varia H: Acute abdomen due to spontaneous splenic rupture as the first presentation of lung malignancy: a case report. J Med Case Reports 2011, 5:444.

324. Tresallet C, Thibault F, Cardot V, Baleston F, Nguyen-Thanh Q, Chigot JP, et al: Spontaneous splenci rupture during intrasplenic Kaposi's sarcoma in an HIV-positive patients. Gastroenterol Clin Biol 2005, 29:1296-1297.

325. Charters JW, Prince G, McGarry JM: Granulosa cell tumour presenting with haemoperitoneum and splenic rupture. Case report. Br J Obstet Gynaecol 1989, 96:735-736

326. Hassan KS, Cohen HI, Hassan FK, Hassan SK: Unusual case of pancreatic inflammatory myofibroblastic tumor associated with spontaneous splenic rupture. World J Emerg Surg 2010, 5(1):28.

327. Burg MD, Dallara JJ: Rupture of a previously normal spleen in association with enoxaparin: An unusual cause of shock. J Emerg Med 2001, 20(4):349-352

328. Weiss SJ, Smith T, Laurin E, Wisner DH: Spontaneous splenic rupture due to subcutaneous heparin therapy. J Emerg Med 2000, 18(4):421-426.

329. Blankenship JC, Indeck M: Spontaneous splenic rupture complicating anticoagulant or thrombolytic therapy. Am J Med 1993, 94(4):433-437.

330. Kapan M, Kapan S, Karabicak I, Bavunoglu I: Simultaneous rupture of the liver and spleen in a patient on warfarin therapy: report of a case. Surg Today 2005, 35:252-255. 
331. Ghobrial MW, Karim M, Mannam S: Spontaneous splenic rupture following the administration of intravenous heparin: case report and retrospective case review. Am J Hematol 2002, 71:314-317.

332. Abad C, Fernández-Bethencourt M, Ortiz E, Rodríguez San Román JL, Facal $P$, Avila R: Spontaneous rupture of the spleen in a patient hypercoagulated with dicumarol. Rev Esp Enferm Dig 1992, 81:366-367.

333. Badaoui R, Chebboubi K, Delmas J, Jakobina S, Mahjoub Y, Riboulot M: Rupture de la rate et anticoagulant. Ann Fr Anesth Reanim 2004, 23(7):748-750.

334. Gernigon Y, Beaumont E, Griffe J: Rupture spontanée de la rate chez un malade traité par les anticoagulants. Arch Med Ouest 1980, 12:163-167.

335. Jabbour M, Tohmé C, Ingea H, Farah P: Spontaneous splenic rupture due to heparin. Report of a case and review of the literature. J Med Liban 1995, 43:107-109.

336. Reches A, Almog R, Pauzner D, Almog B, Levin I: Spontaneous splenic rupture in pregnancy after heparin treatment. BJOG 2005, 112:837-838.

337. Kim H, Lee G, Park DJ, Lee JD, Chang S: Spontaneous splenic rupture in a hemodialysis patient. Yonsei Med J 2005, 46(3):435-438.

338. Jayamaha AS, Patel JK, Orlikowski C: Splenic rupture following streptokinase therapy. Intensive Care Med 1994, 20:244

339. Gardner-Medwin J, Sayer J, Mahida YR, Spiller RC: SPONTANEOUS RUPTURE OF SPLEEN FOLLOWING STREPTOKINASE THERAPY. Lancet 1989, 334(8676):1398.

340. Wiener RS, Ong LS: Streptokinase and splenic rupture. Am J Med 1989, 83:249.

341. Lambert GW, Cook PS, Gardiner GA Jr, Regan JR: Spontaneous splenic rupture associated with thrombolytic therapy and/or concomitant heparin anticoagulation. Cardiovasc Intervent Radiol 1992, 15:177-179.

342. Cheung PK, Arnold JM, McLarty TD: Splenic hemorrhage: a complication of tissue plasminogen activator treatment. Can J Cardiol 1990, 6:183-185

343. Watring NJ, Wagner TW, Stark JJ: Spontaneous splenic rupture secondary to pegfilgrastim to prevent neutropenia in a patient with non-small-cell lung carcinoma. Am J Emerg Med 2007, 25(2):247-248.

344. Arshad M, Seiter K, Bilaniuk J, Qureshi A, Patil A, Ramaswamy G, et al: Side effects related to cancer treatment: Case 2. Splenic rupture following pefgilgrastim. J Clin Oncol 2005, 23:8533-8534.

345. Falzetti F, Aversa F, Minelli O, Tabilio A: Spontaneous rupture of spleen during peripheral blood stem-cell mobilisation in a healthy donor. Lancet 1999, 353(9152):555.

346. Dincer AP, Gottschall J, Margolis DA: Splenic rupture in a parental donor undergoing peripheral blood progenitor cell mobilization. J Pediatr Hematol Oncol 2004, 26:761-763.

347. Pitini V, Ciccolo A, Arrigo C, Aloi G, Micali C, La Torre F: Spontaneous rupture of spleen during periferal blood stem cell mobilization in a patient with breast cancer. Haematologica 2000, 85(5):559-560.

348. Rossitto M, Versaci A, Barbera A, Broccio M, Lepore V, Ciccolo A: Spontaneous rupture of the spleen in a patient treated with chemotherapy and growth factors for stem cell mobilization]. G Chir 1998, 19:204-206.

349. de Lezo Suarez j, Torres A, Herrera I, Pan M, Romero M, Pavlovic D, et al: Effects of stem-cell mobilization with recombinant human granulocyte colony stimulating factor in patients with percutaneously revascularized acute anterior myocardial infarction. Rev Esp Cardiol 2005, 58:253-261.

350. Balaguer H, Galmes A, Ventayol G, Bargay J, Besalduch J: Splenic rupture after granulocyte-colony-stimulating factor mobilization in a peripheral blood progenitor cell donor. Transfusion 2004, 44:1260-1261.

351. Becker PS, Wagle M, Matous S, Swanson RS, Pihan G, Lowry PA, et al: Spontaneous splenic rupture following administration of granulocyte colony-stimulating factor (G-CSF): occurrence in an allogeneic donor of peripheral blood stem cells. Biol Blood Marrow Transplant 1997, 3:45-49.

352. Stuart D, Wolfer R: Spontaneous splenic rupture following administration of granulocyte colony-stimulating factor (G-CSF): a rare but fatal complication. J Surg Res 2007, 137:306-307.

353. Loizon P, Nahon P, Founti H, Delecourt P, Rodor F, Jouglard J: Spontaneous rupture of the spleen under ticlopidine. Apropos of two cases. J Chir (Paris) 1994, 131:371-374.

354. Mitchell C, Riley CA, Vahid B: Unusual Complication of Heparin-Induced Thrombocytopenia After Mitral Valve Surgery: Spontaneous Rupture of Spleen. Ann Thorac Surg 2007, 83(3):1172-1174.
355. Buciuto R, Kald A, Borch K: Spontaneous rupture of the spleen. Eur J Surg 1992, 158(2):129-130.

356. Morrin FJ, Guiney E: Spontaneous rupture of the normal spleen. Ir J Med Sci 1960, 36(11):500-505.

357. Rice JP, Sutter CM: Spontaneous splenic rupture in an active duty Marine upon return from Iraq: a case report. J Med Case Reports 2010, 4:353.

358. Arnold RE, Van Vooren A: Spontaneous rupture of the spleen with hematoma. South Med J 1975, 68(7):863-864.

359. Grech A: Spontaneous rupture of spleen. Br Med J 1971, 1(5740):111.

360. Lennard TW, Burgess P: Vomiting and "spontaneous" rupture of the spleen. Br J Clin Pract 1985, 39:407-410.

361. Toubia NT, Tawk MM, Potts RM, Kinasewitz GT: Cough and spontaneous rupture of a normal spleen. Chest 2005, 128(3):1884-1886.

362. Wehbe E, Raffi S, Osborne D: Spontaneous splenic rupture precipitated by cough: a case report and a review of the literature. Scand J Gastroenterol 2008, 43(5):634-637.

363. Wergowske GL, Carmody TJ: Splenic Rupture From Coughing. Arch Surg 1983, 118(10):1227-a.

364. Kara E, Kaya Y, Zeybek R, Coskun T, Yavuz C: A case of diaphragmatic rupture complicated with laceration of stomach and spleen caused by a violent cough presenting with mediastinal shift. Ann Acad Med Singapore 2004, 33(649):650.

365. Thomas WEG: Apparent spontaneous rupture of the spleen. Br Med J 1978, 1(6110):409-410.

366. Lorimer WS Jr: Occult Rupture of the Spleen. AMA Arch Surg 1964, 89(3):434-440.

367. Vas W, Friend WD: Rupture of a normal spleen caused by vomiting following a metrizamide myelogram. Diagn Imaging 1981, 50(6):309-312.

368. Lemon M, Dorsch M, Street $K$, Cohen $R$, Hale P: Splenic rupture after vomiting. JRSM 2001, 94(10):527-528.

369. Badenoch DF, Maurice HD, Gilmore OJ: Spontaneous rupture of a normal spleen. J R Coll Surg Edinb 1985, 30(5):326-327.

370. Baker AM, Adair NE: Acute hypercapnia and hemodynamic collapse in a 54-year-old man. Chest 1995, 108:266-268.

371. Behera A, Aggarwal S, Kaman L: Spontaneous rupture of normal spleen. Indian J Gastroenterol 1997, 16(2):71-72.

372. Bird D, Kelly MJ, Baird RN: Spontaneous rupture of the normal spleen: Diagnosis by computerized tomography. Br J Surg 1979, 66(8):598.

373. Brodman HR, Bautista J: Spontaneous rupture of the normal spleen: review of the literature and report of one case. AMA Arch Surg 1959, 78(3):406-409.

374. Ceulemans B: Les ruptures spléniques pathologiques. Louvain Med 2002, 121:125-132.

375. Choudhury AK: Spontaneous rupture of a normal spleen. Injury 2004, 35(3):325-326

376. Coote JM, Eyers PS, Walker A, Wells IP: Intra-abdominal bleeding caused by spontaneous rupture of an accessory spleen: the CT findings. Clin Radiol 1999, 54:689-691.

377. Delaney PV: Spontaneous rupture of a normal spleen. J Ir Med Assoc 1972, 65(8):211.

378. Gallerani M, Vanini A, Salmi R, Bertusi M: Spontaneous rupture of the spleen. Am J Emerg Med 1996, 14(3):333-334.

379. Gedik E, Girgin S, Aldemir M, Keles C, Tuncer MC, Aktas A: Non-traumatic splenic rupture: Report of seven cases and review of the literature. World J Gastroenterol 2008, 14(43):6711-6716.

380. Graham JW: Spontaneous rupture of the normal spleen. Med J Aust 1960, 47(1):295-296

381. Gue S: Spontaneous rupture of the normal spleen. Ceylon Med J 1978, 23(1):23-25

382. Huang JF, Hsieh YH, Chen HY: Spontaneous spleen rupture diagnosed by abdominal sonography in a patient without underlying spleen pathology. Ultrasound Med Biol 2006, 32(5 supplement):P224.

383. Kiev J, Rothenberg B, Nance FC: Atraumatic splenic rupture in a healthy adult. Am Surg 1991, 57:727-729.

384. Kumar S, Gupta A, Shrivastava UK, Mathur SB: Spontaneous rupture of normal spleen: an enigma recalled. Br J Clin Pract 1992, 46(1):67-68.

385. Laseter T, McReynolds T: Spontaneous splenic rupture. Mil Med 2004, 169(8):673-674

386. Mockford BJ, Brown RJ: An unusual case of delayed rupture of the spleen associated with pectus excavatum. Ulster Med J 2002, 71:60-61. 
387. Moran JC, Shah U, Singer JA: Spontaneous rupture of a wandering spleen: case report and literature review. Curr Surg 2003, 60(3):310-312.

388. Perl Jl, Darter RW, Milles G: Spontaneous rupture of a normal spleen: report of a case. J Int Coll Surg 1958, 30(4):420-424.

389. Stewart GR, Braasch JW: Spontaneous occult rupture of a normal spleen. Med J Aust 1971, 1(4):203-205.

390. Vahid B, Bosanac A, Marik P: Spontaneous rupture of the normal spleen: A case report. Surgery On-line 2005 2010,

391. Carles J, Guegan H, Crozat T, Janvier G, Riant T, Videau J: Spontaneous rupture of the spleen disclosing pheochromocytoma. J Chir 1990, 127:464-467.

392. Sowers N, Aubrey-Bassler FK: Trivial trauma and delayed rupture of a normal spleen: a case report. J Med Case Reports 2011, 5:591.

393. Douglas GJ, Simpson JS: The conservative management of splenic trauma. J Pediatr Surg 1971, 6(5):565-570.

394. Sjövall A, Hirsch K: Blunt abdominal trauma in children: Risks of nonoperative treatment. J Pediatr Surg 1997, 32(8):1169-1174.

395. Kluger Y, Paul DB, Raves JJ, Fonda M, Young JC, Townsend RN, Diamond D: Delayed rupture of the spleen-myths, facts, and their importance: case reports and literature review. J Trauma 1994, 36(4):568-571.

396. Allen TL, Greenlee RR, Price RR: Delayed splenic rupture presenting as unstable angina pectoris: case report and review of the literature. J Emerg Med 2002, 23(2):165-169.

397. Petitjean ME, Riant T, Tentiller E, Simonnet G, Janvier G, Erny P: Spontaneous splenic rupture disclosing a pheochromocytoma. Can J Anaesth 1992, 39:495-498.

398. Fried K, Kaufman S: Congenital afibrinogenemia in 10 offspring of uncle-niece marriages. Clin Genet 1980, 17:223-227.

399. Vaiberg D, Sidlovsky S, Chris SM: Spontaneous rupture of spleen: report of a case. Can J Surg 1965, 8:96.

400. Nicoll JAV: Splenic haematoma after spontaneous rupture of the spleen. Am J Surg 1968, 116:117-118.

401. Crate ID, Payne MJ: Is the diagnosis of spontaneous rupture of a normal spleen valid? J R Army Med Corps 1991, 137(1):50-51.

402. Husni EA, Turell D: Spontaneous Rupture of the Normal Spleen: Does It Occur Without Trauma or Antecedent Disease? AMA Arch Surg 1961, 83(2):286-290

403. Tataria M, Dicker RA, Melcher M, Spain DA, Brundage SI: Spontaneous splenic rupture: the masquerade of minor trauma. J Trauma-Injury Infection \& Critical Care 2005, 59(5):1228-1230.

404. In Pediatric and Adult Emergency Medicine): UpToDate: Version 18. Edited by Fleisher GR, Marx JA, Walls RM, Grayzel J, Wiley JF. Waltham, MA: UpToDate; 2011. www.uptodate.com.

doi:10.1186/1471-227X-12-11

Cite this article as: Aubrey-Bassler and Sowers: 613 cases of splenic rupture without risk factors or previously diagnosed disease: a systematic review. BMC Emergency Medicine 2012 12:11.

\section{Submit your next manuscript to BioMed Central and take full advantage of:}

- Convenient online submission

- Thorough peer review

- No space constraints or color figure charges

- Immediate publication on acceptance

- Inclusion in PubMed, CAS, Scopus and Google Scholar

- Research which is freely available for redistribution 